This PDF is a selection from a published volume from the National Bureau of Economic Research

Volume Title: Labor in the New Economy

Volume Author/Editor: Katharine G. Abraham, James R. Spletzer, and Michael Harper, editors

Volume Publisher: University of Chicago Press

Volume ISBN: 978-0-226-00143-2; 0-226-00143-1

Volume URL: http://www.nber.org/books/abra08-1

Conference Date: November 16-17, 2007

Publication Date: October 2010

Chapter Title: Recent Trends in Compensation Inequality

Chapter Author: Brooks Pierce

Chapter URL: http://www.nber.org/chapters/c10814

Chapter pages in book: $(63$ - 98) 


\title{
Recent Trends in Compensation Inequality
}

\author{
Brooks Pierce
}

\subsection{Introduction}

While changing wage inequality in the United States is the subject of a large and vibrant literature, relatively little is known about changing inequality of compensation more broadly defined. Workers choose jobs partly on the basis of the job's wage-benefits mix, and higher-wage workers are likely to choose different mixes than lower-wage workers for a number of reasons. Furthermore, employers' provision of benefits such as health insurance and pensions, and the costs associated with those benefits, have changed substantially over the recent past. Such changes impact high- and low-wage workers differently, and one might expect compensation and wage inequality to differ in systematic and changing ways.

This chapter documents changing compensation costs for labor, and changing compensation inequality, using employer survey microdata on wages and benefit costs. These data are rather unique in that they capture employer cost information for wages as well as a broad array of benefits including health insurance, defined benefit pensions and defined contribution retirement savings plans, and paid leave. These data allow one to compare the wage distribution to the distribution of employer costs, as defined to include these forms of compensation. The data also allow one to isolate changes in particular benefits by position in the wage distribution. Did the run-up in health insurance costs over the past decade impact high- or low-

Brooks Pierce is a research economist in the Compensation Research and Program Development group at the Bureau of Labor Statistics.

Views expressed are my own and do not reflect the views or policies of the Bureau of Labor Statistics (BLS) or any other agency of the U.S. Department of Labor. 
wage workers more? Have increased bonuses been isolated in the highestwage jobs?

The employer survey data on fringe benefits and wage costs show changing wage inequality broadly consistent with tabulations from household survey data sources (Autor, Katz, and Kierney 2008; Lemieux, chapter 1 in this volume). Wage inequality grew over the two-decade period from 1987 to 2007. Wage compression occurred in the bottom half of the wage distribution, especially over the 1987 to 1997 decade. Higher-end wages grew more than median or lower-end wages throughout these two decades.

The employer cost data also indicate that benefits' costs to employers rose more in high-wage than low-wage jobs. This differential growth was great enough so that inequality in compensation more broadly defined grew at least as much as did inequality in wages. In terms of particular fringe benefits, health insurance costs rose substantially, especially over the 1997 to 2007 period. Health insurance costs as a fraction of wages rose especially in jobs with wages near the median. Rising pension costs in the last decade added to compensation growth in above-median wage jobs. There is also some evidence that variable pay such as sales commissions and bonuses played a role in compensation growth in high-wage jobs.

I augment these data on employer-provided fringe benefits with data on another important job-related amenity, workplace safety. The substantial decline in the risk of workplace injuries over the recent past is underappreciated in the labor economics literature (Nestoriak and Ruser, chapter 11 in this volume). This secular trend toward lower risk is evident in the risk of both fatal and nonfatal injury. Although it is difficult to cost-out workplace safety as a fringe benefit, the data do allow one to compare changing job-related risks of injury or fatality in high- and low-wage sectors of the economy. The improvement in workplace safety was wide ranging in that it occurred for a wide variety of occupations and, therefore, presumably for workers throughout the wage spectrum.

\subsection{The Employment Cost Index (ECI) Data}

The data on fringe benefits costs used in this chapter are from the employer survey microdata used to produce the Employment Cost Index (ECI). The $\mathrm{ECI}$ is a quarterly index measuring changes over time in the cost of wages and various nonwage compensation costs. The ECI survey scope is the civilian workforce, excluding agricultural, federal government, self-employed, and private household workers. The ECI survey is an establishment-based survey, meaning that establishments rather than firms are selected for inclusion in the sample. Within a sampled establishment, one to eight jobs are selected, depending on establishment employment. The unit of observation in the microdata is, therefore, a "job," as determined primarily by the employer-assigned job title. Information is collected on the wages, other 
compensation costs, and work schedules of the individual incumbents in the sampled jobs. Various categories of nonwage compensation are collected, including health and life insurance, several forms of leave, pension and savings plans, bonuses, and legally required expenditures on Social Security, workers' compensation, and unemployment insurance. This data is converted to a cost per hour worked and averaged over the incumbents within a job. Data are collected quarterly; quarterly samples over the 1987 to 2007 period average about 30,000 job observations from 7,000 establishments.

Several caveats are in order. The cost data refer to employer costs, which will differ from employee valuations due to tax and other considerations (Famulari and Manser 1989). The data are subject to nontrivial measurement error. The survey attempts to collect data at the level of the job, but respondents may only be able to report data relevant for a broader group of workers than the job incumbents. For instance, a respondent might report an establishment-wide average for white collar workers' health insurance premiums, or an establishment average employer contribution rate to a defined contribution plan. Also, the data miss variation in wages and benefit costs across workers in the same job and establishment. ${ }^{1}$ The data do not contain information on job incumbents, such as gender or schooling levels. Much wage inequality research, by contrast, separately describes the experiences of men and women and investigates changing returns to schooling as a contributory factor to inequality changes. Nonetheless, these data are some of the best available for this particular application as they span a substantial time period, include cost measures for several important fringe benefits, and are derived from employer and administrative records.

Table 2.1 gives sample means for various periods. The table gives costs per hour worked, benefits' share of total compensation, and an incidence rate for some key benefit categories. Because cost data are averaged over job incumbents, the fraction of jobs with positive employer costs exceed true coverage rates that would be derived from individual data. The hourly wage rate is a straight-time hourly earnings figure adjusted to include overtime premium pay and shift differentials. Cost figures are deflated to 2007 dollars using the Consumer Price Index for All Urban Consumers (CPI-U). The data are hours-weighted for all statistics presented in this chapter. However, published tabulations by the Bureau of Labor Statistics (BLS) using these data do not weight by hours worked. Hours-weighting facilitates a comparison with most recent published studies on wage inequality using other data such as the Current Population Survey (CPS).

1. Certain job characteristics (full-time status, union status, and presence of piece rates or commissions) that correlate with pay and benefits provision also enter into the definition of the "job." For example, full-time and part-time workers in the same establishment and with the same job title are separately subject to being sampled. Hence, differences in wages and benefits attributable to full-time status are captured in the survey and are not averaged away in computing a job-level statistic. 
Table 2.1 Sample means

\begin{tabular}{lrrrr}
\hline & 1987 & 1997 & 2007 & $\begin{array}{c}\text { Whole period } \\
\text { average }\end{array}$ \\
\hline Employer costs per hour (\$) & & & & \\
$\quad$ Wage & 19.66 & 18.91 & 20.55 & 19.57 \\
Compensation & 26.66 & 26.12 & 29.15 & 27.11 \\
Health insurance & 1.31 & 1.57 & 2.30 & 1.77 \\
Retirement and savings & 1.20 & 1.05 & 1.25 & 1.08 \\
$\quad$ Paid leave & 2.01 & 1.84 & 2.16 & 1.97 \\
Benefit's share in compensation & & & & .063 \\
$\quad$ Health insurance & .048 & .058 & .078 & .063 \\
Retirement and savings & .035 & .030 & .032 & .030 \\
Paid leave & .067 & .061 & .062 & .063 \\
Other nonlegally required & .012 & .014 & .013 & .013 \\
$\quad$ Legally required & .088 & .094 & .089 & .092 \\
Fraction of jobs reporting positive costs & & & & .808 \\
$\quad$ Health insurance & .851 & .789 & .789 & .671 \\
Retirement and savings & .663 & .665 & .700 & .917 \\
Paid leave & .930 & .904 & .905 & \\
\hline
\end{tabular}

Notes: Cost figures are in CPI-U deflated 2007 dollars. "Retirement and savings" category includes defined benefit pensions and defined contribution plans. "Paid leave" includes vacations, holidays, sick leave, and other paid leave. "Other nonlegally required" benefits include nonproduction bonuses, severance pay, life insurance, sickness and accident insurance, and supplemental unemployment insurance. "Legally required" category includes Social Security, Medicare, Worker's Compensation, and state and federal unemployment insurance.

For the period as a whole, about 74 percent of ECI compensation takes the form of wages, and about 26 percent of compensation is in the form of benefits. The costliest single benefit is health insurance, with average expenditures of $\$ 1.77$ per hour worked. Retirement and savings benefits costs are fairly substantial at $\$ 1.08$ per hour worked. Retirement benefits include defined benefit pensions as well as defined contribution vehicles, such as 401(k) and deferred profit sharing plans. The ECI data reflect current pension costs, which in the case of defined benefit plans, can vary with pension asset returns and firms' chosen liability accounting methods. Therefore, these costs can only approximate the long-run actuarial obligation associated with a pension plan. Paid leave of various sorts accounts for costs of $\$ 1.97$ an hour, on average. Leave is an aggregate of paid vacation time, holidays, sick leave, and an "other" category. Of these, the vacation and holidays components are the most important. Vacation and holiday benefits are each typically collected in time units at some accrual rate (four hours per biweekly pay period, eight days per year, etc.), converted to an hours accrued per hour worked basis and then valued at the job's hourly wage. Leave may simply represent one margin of labor supply, or leave plans may reflect firms' attempts to monitor and coordinate work time. I interpret leave to also represent some flexibility to the worker in scheduling hours or coordinating time for nonwork purposes. 
Paid leave benefits are probably not captured as part of the calculated wage in household survey data such as the CPS, as those calculations include earnings while on leave but probably do not adjust the hours worked to reflect leave time. Leave is treated here as a "benefit" in an attempt to parallel CPS measures. The chapter later gives results for separate benefit components so that this treatment of leave does not obscure results for health insurance or retirement plans.

Table 2.1 also reports summary statistics on benefit shares in compensation and the fraction of the data with positive employer costs for the various benefit categories. About 9.2 percent of compensation costs come in the form of legally required compensation, the bulk of which is attributable to Social Security, Medicare, and Worker's Compensation. Leave and health insurance shares are each 6.3 percent. The retirement savings category accounts for 3 percent of hourly employer costs, and miscellaneous other nonlegally required benefits (mainly nonproduction bonuses) account for a little more than 1 percent of compensation, on average. Almost 92 percent of the sample has some positive leave costs, about 81 percent have some positive health insurance costs, and about 67 percent have some positive retirement vehicle costs.

Table 2.1 gives beginning- and end-of-period statistics as well. Real hourly wage rates in this sample grew 4.5 percent, and real hourly compensation grew about 8.7 percent over this period. These growth rates were larger in the second half of this period. Among the benefit categories, health insurance and retirement plan costs rose the most. Note that the whole-period average health insurance costs are similar to the 1997 level. Health insurance premiums have grown at a faster rate than benefit costs in general, except for a brief period in the mid- to late-1990s. ${ }^{2}$ There was a slight decrease in the fraction of jobs reporting positive health insurance costs. Not apparent from table 2.1 is the shift toward defined contribution plans, which tend to have lower reported employer costs. That shift has been accompanied by an increase in the overall fraction of jobs reporting positive retirement plan costs.

\subsection{Wage Inequality in the ECI and CPS}

One useful exercise is to compare wage dispersion in the ECI to similar statistics derived from CPS data. It would be convenient if the two data sets showed substantially similar trends in dispersion. In that case, one could more confidently imagine measured ECI effects on inequality due to health insurance and so forth as applying in a straightforward manner to the betterdocumented CPS trends. However, the two data sets do give noticeably different results for some inequality growth measures. The largest difference 
between the data sources appears to be the fact that measured wage growth in the last decade is larger in CPS than ECI data in the upper quintile of the wage distribution. This may reflect different samples or different wage measures, but, in any case, it suggests that readers should exercise proper caution in generalizing ECI trends to other data sources.

Although the ECI and CPS data are collected and processed in quite different ways, the CPS can be restricted to a sample with scope ostensibly similar to the ECI scope. As a practical matter, this mainly involves using CPS self-reports on employment status in the "class of worker" fields to eliminate federal government and self-employed workers. This is a crude proxy for the restrictions in the ECI survey scope that operate implicitly through the BLS sampling frame for establishment surveys, which is constructed mainly from required unemployment insurance (UI) reports.

To construct a CPS data sample, I take outgoing rotation group (CPS ORG) data on earnings for the period 1989 to 2007. The sample excludes agricultural industries, federal government and postal workers, the selfemployed, and private household workers. Federal workers are identified separately from state and local government workers beginning in 1989. Hourly earnings are hourly wage rates for those reporting earnings on an hourly basis and are usual weekly earnings divided by usual hours worked per week for those reporting earnings with other than hourly periodicity.

The resulting CPS samples have lower wages than the ECI data; the 1989 to 2007 whole period average is $\$ 19.56$ in the ECI versus $\$ 18.53$ in the CPS. This is consistent with a view, for example, that the ECI sample panel data reflects the experience of somewhat longer-lived establishments. Both the CPS and ECI data exhibit slight decreases in real wages in 1989 to 1995, increases over the 1996 to 2002 period, and little change post-2002.

Possibly a more relevant consideration relates to how the ECI and CPS wage inequality trends compare. To facilitate comparison to more standard CPS data results, this chapter focuses primarily on wage percentiles although some statistics do refer to compensation percentiles. I define percentiles to include the 1 percent of the (weighted) data centered on the relevant percentile value. Statistics of interest are averaged within percentile so defined. This averaging abstracts from the within-percentile variation in benefit costs and other data elements. Smoothing away variation in benefit costs or benefit shares within percentile helps extract most of the information in the data in a nonparametric fashion. ${ }^{3}$

Figures 2.1 and 2.2 give wage growth by percentile for the CPS and ECI data for the 1989 to 1997 and 1997 to 2007 periods. During the 1989 to 1997

3. I compute whole-distribution dispersion measures such as the Gini coefficient on microdata rather than percentile-averaged data. 


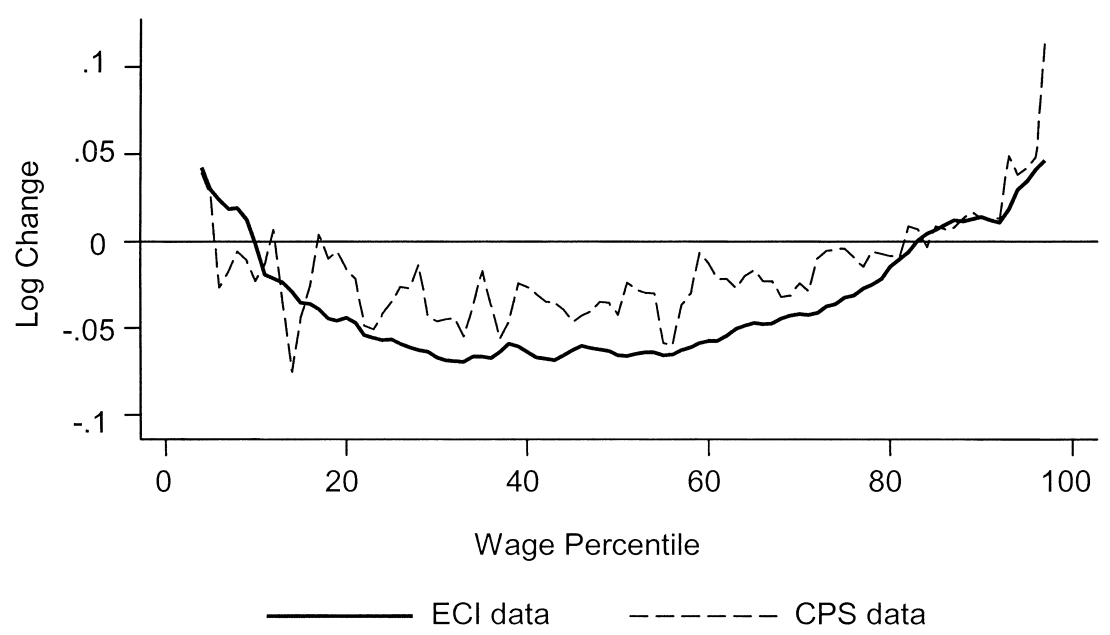

Fig. 2.1 Wage growth by percentile, 1989-1997

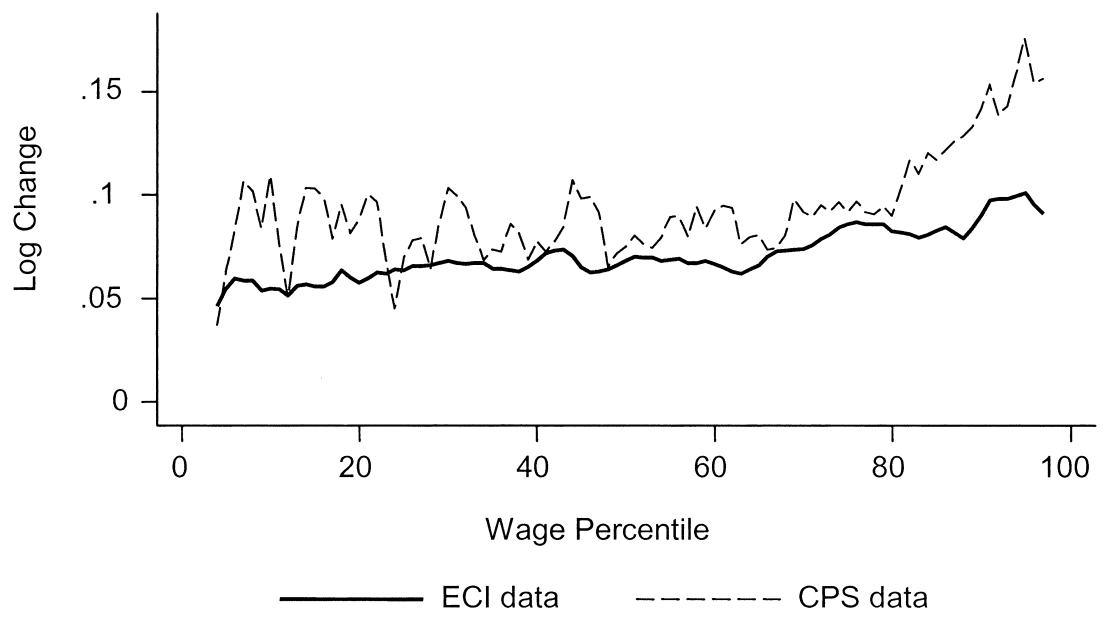

Fig. 2.2 Wage growth by percentile, 1997-2007

period, ECI wages compressed in the bottom of the wage distribution, while wage inequality grew in the top half of the wage distribution. These patterns are evident in this CPS sample and are shown elsewhere in greater detail, for example, see Lemieux (chapter 1 in this volume). During the last decade, wage growth has been more pronounced in the CPS than the ECI, especially at the top end of the wage distribution. The largest difference between the data sources is that wage growth in the upper decile is about $5 \log$ points 
more in the CPS than ECI data. ${ }^{4}$ But in coarse terms, the ECI and CPS tell similar stories about wage dispersion changes.

\subsection{The Cross-Sectional Relationship between Benefits Costs and Wages}

The cross-sectional relationships between benefits costs and wages are well-established (Woodbury 1983). Nevertheless, it is useful to document them here as a prelude to understanding benefit inequality growth.

Looking at benefit costs as a share of total compensation is a useful device to understand how the wage differential between two jobs compares to the analogous compensation differential. Define total compensation per hour, $c$, as wages per hour, $w$, plus various benefits per hour, $b_{j}$,

$$
\begin{aligned}
c & =w+\sum_{j} b_{j}=w+\sum_{j} s_{j} c \\
& =w+s c \\
& =\frac{w}{1-s},
\end{aligned}
$$

where $s_{j}=b_{j} / c$ is benefit $j$ 's share in total compensation, and $s$ is the sum of these shares over the benefit components indexed by $j$. Then, for example, the log compensation differential between jobs at the 90th percentile wage and the median wage can be written as

$$
\begin{aligned}
\ln \left(c^{90}\right)-\ln \left(c^{50}\right) & =\ln \left(w^{90}\right)-\ln \left(w^{50}\right)-\left[\ln \left(1-s^{90}\right)-\ln \left(1-s^{50}\right)\right] \\
& \approx \ln \left(w^{90}\right)-\ln \left(w^{50}\right)+\frac{\left(s^{90}-s^{50}\right)}{1-\bar{s}},
\end{aligned}
$$

where superscripts refer to location in the wage distribution and where $\bar{s}$ is the average of the 90th percentile and median benefit shares. Note that the benefit cost share at any percentile can further be split into component $\left(s_{j}\right)$ parts.

This accounting framework helps in describing contributions of separate benefits to inequality or inequality changes. It, in essence, treats benefit costs as a fractional add-on to wages and asks how much the add-on differs across the wage distribution and how the add-on difference changes through time. ${ }^{5}$

4. One possible cause for such differences lies in the fact that the ECI data tend to incorporate more averaging (across quarters and, especially, across individuals within a single sampled job). For example, the greater percentile-to-percentile variation in the CPS data evident in these figures, especially below the median, partially reflects a greater bunching of observations at round nominal dollar figures.

5. Relationships like equation (1) are more simply derived using a benefit add-on $(b / w)$ rather than a cost share. Specifying equation (1) in terms of cost shares is attractive mainly in that data are often tabulated and analyzed in this form. Note also that equation (1) uses the same data ordering for both the compensation and wage differentials. Moving from wage to compensation dispersion requires an additional term that quantifies the effects of resorting when moving from a wage to a compensation distribution. 
Figure 2.3 graphs the share of compensation costs taken in the form of benefits against the percentile of the compensation distribution, for the whole 1987 to 2007 period. Voluntary (not legally required) nonwage compensation is shown, along with all nonwage compensation. The benefit shares are relatively smooth increasing functions of the percentile. The immediate implication is that wage differentials tend to understate compensation differentials, especially in the lower half of the wage or compensation distribution. The difference between the two plotted series is attributable to legally required compensation costs. This difference is somewhat larger at lower percentiles, reflecting the fact that some of these costs have fixed cost attributes. For example, unemployment insurance costs are often a percentage of earnings up to some relatively low earnings cutoff.

Figure 2.4 graphs the benefit share in compensation for leave, pensions and savings plans, and health insurance against compensation percentile. The health insurance share is quite low at the 10th percentile, increases rapidly through about the 40th percentile, stays roughly constant in the middle of the distribution, and tails off noticeably above the 60th percentile. Health benefit costs per hour are rising over the entire range but not proportionately with total compensation beyond the 60th percentile. The share falls by about 2 percentage points on a base of about 8 percentage points from the 50th to 90 th percentiles.

The pattern that holds for health insurance is somewhat different from those for leave and pensions. Although retirement compensation represents on average only about 2 to 3 percent of compensation, it can substantially

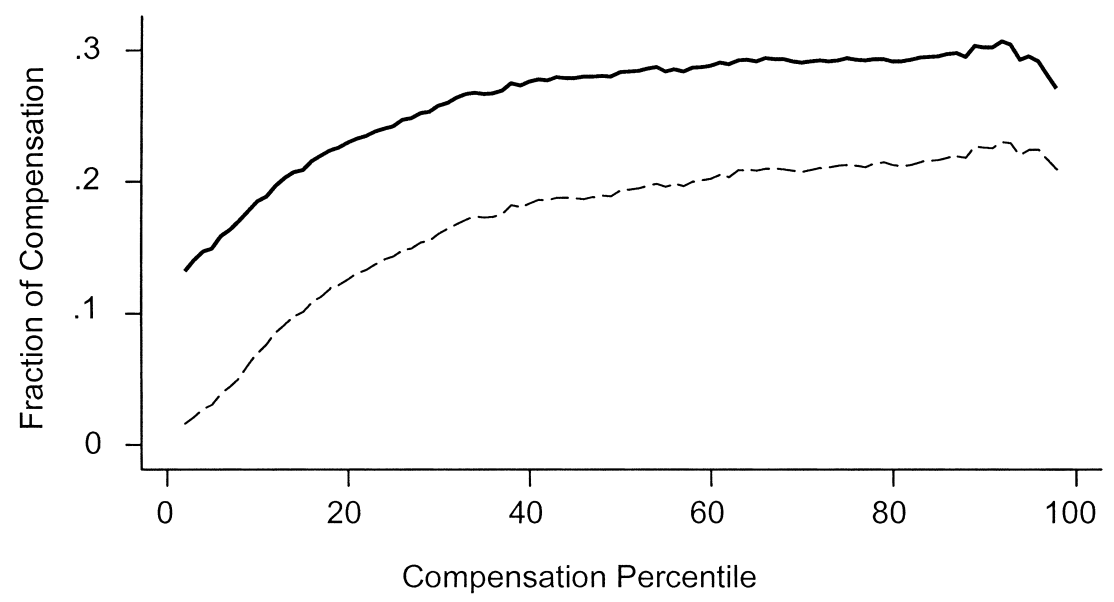

- - - - - Not Legally Required

All Benefits

Fig. 2.3 Benefit share of compensation, 1987-2007 average, by compensation percentile 


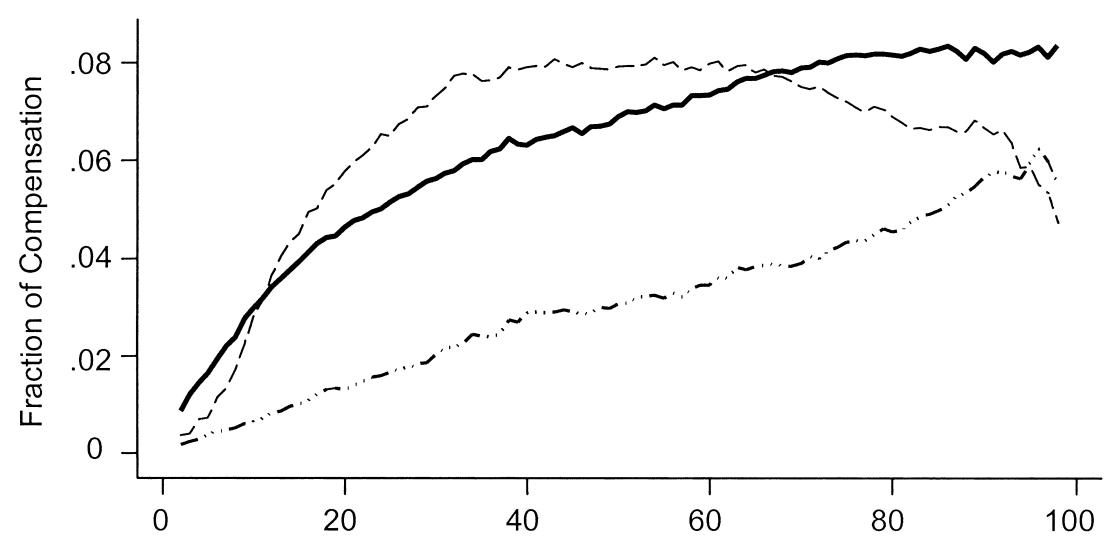

Compensation Percentile

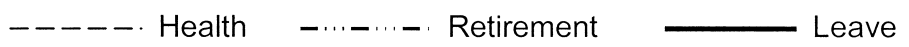

Fig. 2.4 Component benefit shares, 1987-2007 average, by compensation percentile

affect inequality calculations. Jobs in the bottom quartile of the compensation distribution have very little in the way of retirement benefits, while jobs in the top decile have over 5 percent of compensation in this form. Retirement compensation tends to increase compensation inequality in the upper as well as the lower tail of the distribution. The share of compensation taken as leave increases with compensation but somewhat more rapidly in the lower half of the distribution.

Table 2.2 brings together the results from these figures. The table gives wage and compensation dispersion across various points of the distribution and indicates each group of benefits' contribution to compensation inequality using the approximation in equation (1). For example, the first row indicates that the log wage differential between the 90th and 10th percentile of the wage distribution is 1.468 . The log compensation differential between these two points (again, in the wage distribution) is 1.573. Therefore, about $0.105 \log$ points in compensation dispersion can be attributed to various benefits. Table 2.2 breaks out benefits by type, including "other voluntary" and "legally required" benefits categories. The wage dispersion column and the first four benefits columns add up to the "voluntary dispersion" column; adding in the last benefit component ("legally required") gives the wage-sorted compensation dispersion. The final column of table 2.2 gives compensation dispersion based on the compensation-sorted distribution of the data. Reordering the data by compensation per hour rather than by the wage rate must increase overall compensation dispersion measures.

Consider the broadest range, the 90th to 10 th differential. The leave and 


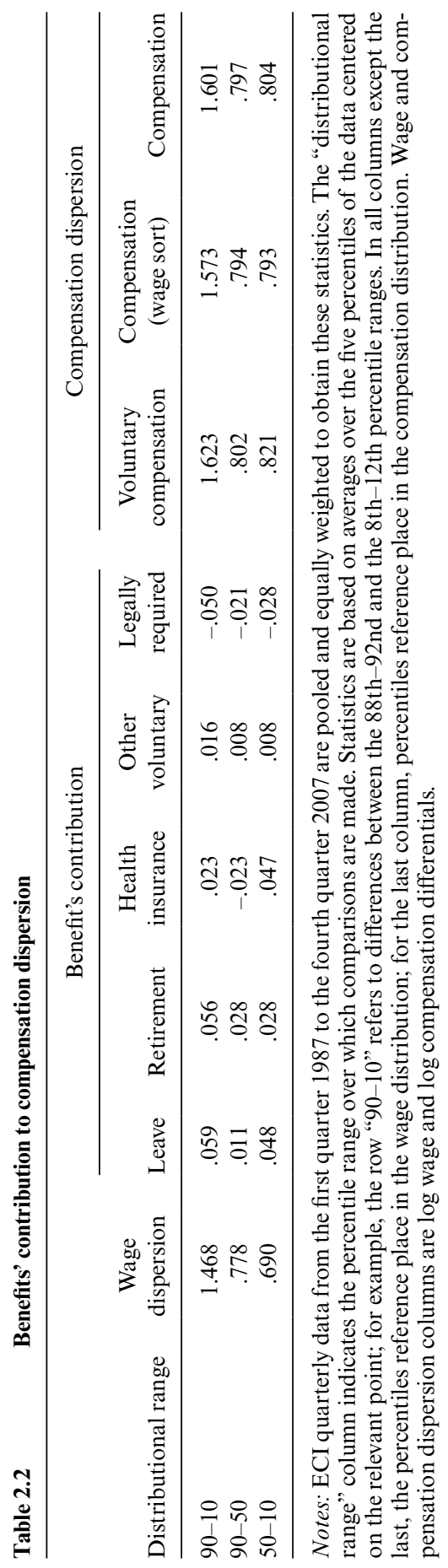


pensions components each add .05 to .06 in log points to measured compensation dispersion. Health insurance adds less, about .023. At least over the whole distribution, leave and pension benefits are more important in determining compensation dispersion than are health insurance benefits. The "other voluntary" category adds about $.016 \log$ points. The sum of these nonlegally required benefits gives 0.154 in log points. Legally required compensation costs tend to equalize the compensation distribution substantially.

There are also interesting differences among benefits components across the various parts of the 90th to 10th percentile range. These differences are apparent in previously referenced figures: leave effects occur mostly in the bottom half of the wage distribution, pension effects operate throughout the distribution, and health insurance is important in adding to dispersion in the lower half of the distribution but is equalizing in the upper half.

\subsection{Changing Wage and Compensation Inequality}

Wage inequality grew over this period in the upper half of the distribution and shrank in the lower half of the distribution. Further, the results in table 2.1 show some benefit cost growth over this period. That growth did not occur uniformly across the wage spectrum. To see the effects on compensation inequality, figure 2.5 overlays plots of real compensation growth by compensation percentile with plots of real wage growth by wage percentile. The top panel gives the whole 1987 to 2007 period, while the bottom panels give two ten-year subperiods. Wage and compensation growth rates were

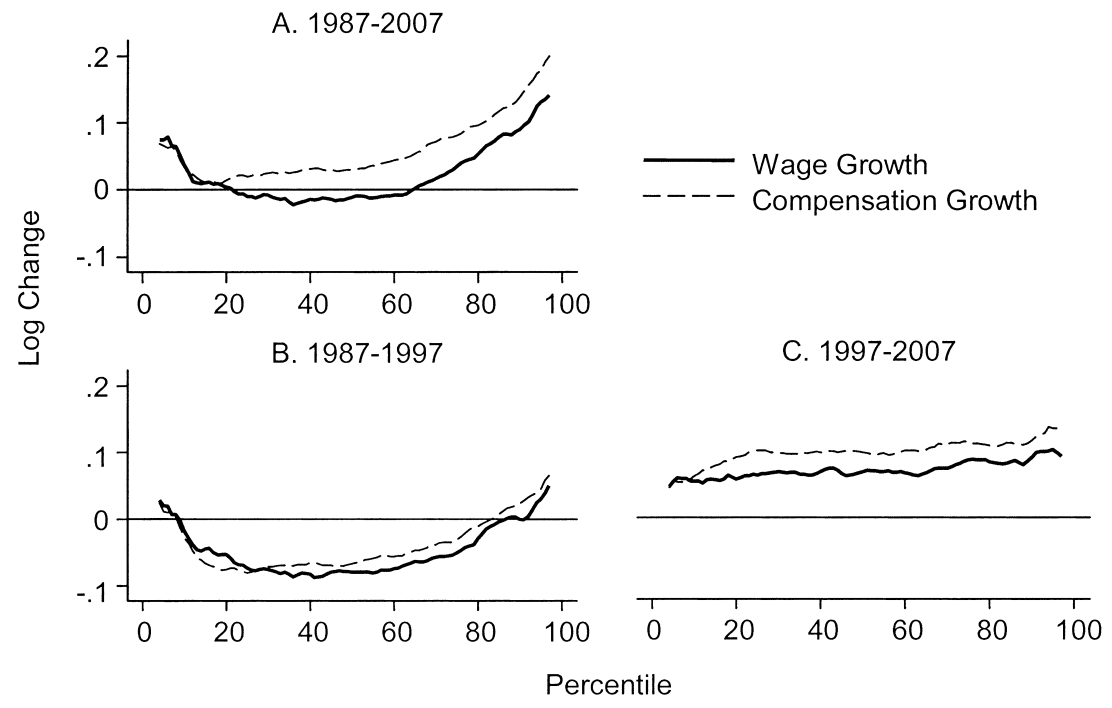

Fig. 2.5 Wage and compensation growth by percentile 
highest above median values, meaning that wage and compensation inequality increased above the median. This was true for the period as a whole as well as for each subperiod taken separately. The greater growth rates below the median than at the median imply reduced inequality among mediumand low-wage jobs. In ECI data, that effect operated in the early but not the later subperiod. Compensation grew slightly faster than wages, on average, with the differences more noticeable in the middle and upper part of the respective distributions. This suggests that below-median compression is slightly more apparent for wages than for overall compensation.

Table 2.3 gives wage and compensation differentials across various parts of the distribution. Overall inequality, as measured by the standard deviation or Gini coefficient, increased slightly for both log wage and log compensation rates in the ECI data. This is true for each subperiod. Of course, the experience above and below median differs. The measured 90-50 differentials indicate increased inequality of $.103 \mathrm{log}$ points for wages and $.110 \mathrm{log}$ points for compensation over the whole period. The analogous 50-10 differential indicate compression of .049 for wages and .007 for compensation. Table 2.3 also shows statistics derived from the CPS ORG data for 1989 to 2007. Although the statistics generally agree with the ECI wage data, the CPS data show greater inequality growth over the 1997 to 2007 subperiod, especially above the median.

To sum up, in the 1987 to 1997 period, there was wage compression below

Table 2.3 Wage and compensation dispersion

\begin{tabular}{lllll}
\hline & \multicolumn{3}{c}{ Percentile differentials } \\
Standard deviation & $90-10$ & $90-50$ & $50-10$ & Gini coefficient \\
\hline
\end{tabular}

I. Employment Cost Index data

A. Log wage

$\begin{array}{lrrrrr}1987 & .564 & 1.456 & .723 & .733 & .317 \\ 1997 & .578 & 1.474 & .804 & .671 & .329 \\ 2007 & .592 & 1.510 & .828 & .684 & .340 \\ \text { Change 1987-2007 } & .029 & .054 & .103 & -.049 & .023 \\ \text { Log compensation } & & & & & \\ 1987 & .597 & 1.563 & .738 & .825 & .326 \\ 1997 & .620 & 1.612 & .829 & .783 & .346 \\ 2007 & .639 & 1.666 & .848 & .818 & .354 \\ \text { Change 1987-2007 } & .042 & .103 & .110 & -.007 & .028\end{array}$

II. Current Population Survey outgoing rotation group data

A. Log wage

\begin{tabular}{lrrrrr}
1989 & .566 & 1.452 & .733 & .719 & .318 \\
1997 & .585 & 1.475 & .780 & .695 & .331 \\
2007 & .608 & 1.530 & .845 & .685 & .343 \\
Change 1989-2007 & .042 & .078 & .112 & -.034 & .035 \\
\hline
\end{tabular}

Note: See text for sample details. 
median and wage expansion above median, and compensation growth modestly exceeded wage growth above the median(s). In the 1997 to 2007 period, compensation growth was greater than wage growth everywhere but at low percentile values. As a result, it appears that compensation growth totalled over the twenty-year period was greater than wage growth and slightly more so in the upper half of the respective distributions.

\subsection{Benefits' Contribution to Inequality Growth}

As discussed previously, changing benefit cost shares give some sense for how compensation and wage growth differ. This section documents individual benefits' contributions to inequality growth by in essence describing how the benefit share-percentile relationships shown in figure 2.4 changed through time.

\subsubsection{Health Insurance}

Health insurance differs from the other main benefit components in that changing relative prices in the form of rising insurance premiums are behind many of the observed changes. Higher health insurance costs have likely induced firm and worker adjustments such as higher plan costs directly borne by the worker, greater firm reliance on part-time workers, and possibly adjustments to wage rates paid. The employer cost data as used here reflect such adjustments as well as the underlying relative price shifts. ${ }^{6}$

Figure 2.6 shows how the benefit share for health insurance has changed, by percentile in the wage distribution. In this figure, the benefit shares for 1987, 1997, and 2007 are smoothed (over wage percentile) and overlaid. Table 2.1 shows that health insurance costs rose at a faster rate than wages over this period. Figure 2.6 also shows greater share growth in the 1997 to 2007 subperiod. This makes some sense in light of health management organization (HMO)-related premium growth slowdown of the mid-1990s, which gave way to more usual rates of medical price inflation by the end of the 1990s.

Health insurance premium growth without other changes would cause proportionate increases (not a parallel shift) in the cost share, but figure 2.6 shows more-than-proportionate increases among jobs with wages in the middle half of the wage distribution. Jobs in the highest quartile experienced substantial benefit cost growth but also experienced rapid wage growth. That accounts for the relatively moderate health insurance share growth in highwage jobs. Jobs in the lower quartile experienced greater wage growth than did jobs in, say, percentiles 30 to 60 . Below-median wage jobs may be ones where worker and firm adjustments occur most. One suspects that part-time

6. For some evidence on the effects of increased health insurance premiums, see Baicker and Chandra (2006). 


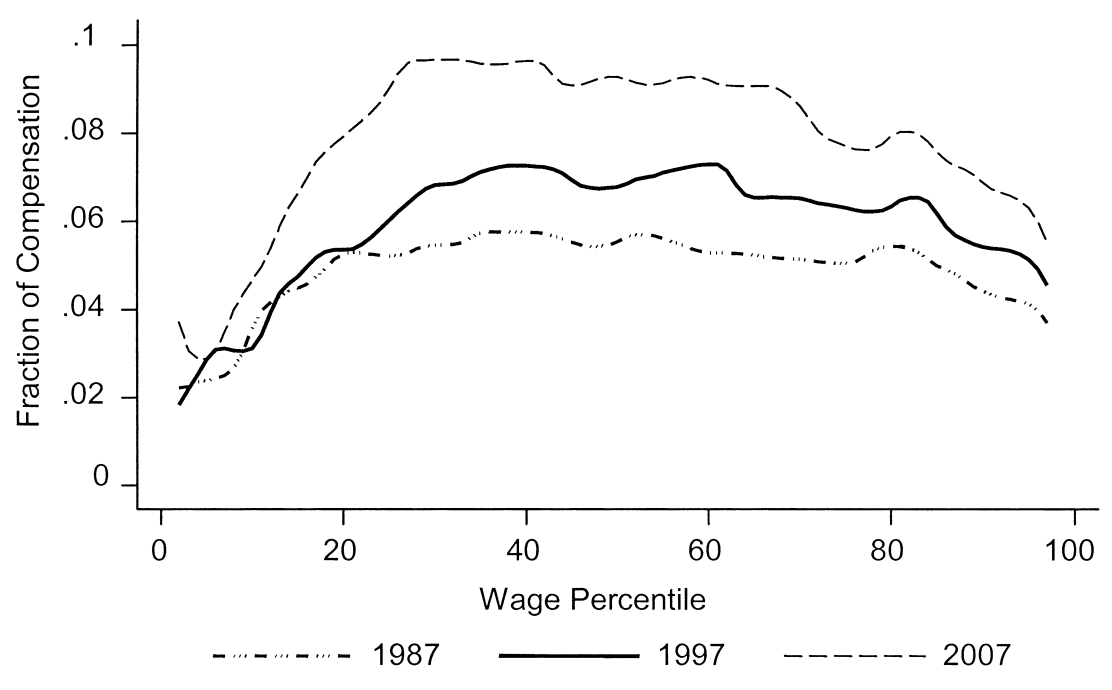

Fig. 2.6 Health insurance share by wage percentile

and full-time jobs are more substitutable from the employer's perspective for jobs with below-median wage rates. It is also possible that lower-wage workers are more price sensitive to health insurance premium growth and that changing health insurance participation plays a role for them as well.

An open question at this point is whether changing offer or take-up rates have affected employers' costs. Because the ECI unit of observation is a job within an establishment, one cannot readily calculate a health insurance coverage rate analogous to what one might calculate from household survey data. The closest construct involves calculating the fraction of the sample with positive employer costs for health plans. Such a calculated fraction is conceptually closer to an employer offer rate than a health insurance coverage rate. If employers continue to offer health plans but fewer workers within a job take up the offer, then the ECI data will tend to reflect that change not as a lower incidence rate but, instead, as lower employer costs for given incidence.

The March CPS is a good source for health insurance coverage rate data (see Levy [2006] and Farber and Levy [2000] for studies using various CPS supplements). The March CPS identifies those with health insurance coverage and determines whether that coverage is through the individual's employer (although we do not know if an uninsured worker's employer offered health insurance). The March CPS supplement data is retrospective in that it asks about earnings and hours worked in jobs in the prior year. The wage measure for the March sample is derived as annual wage and salary earnings, divided by the product of weeks worked and usual hours worked per week in the prior year. I impose several exclusions in the CPS data so that 
it more closely resembles the ECI sample. This primarily involves excluding self-employed workers and workers in the federal sector. I also restrict the CPS sample to full-time, year-round workers. I restrict attention to the 1992 to 2007 period, which is the time frame available at this writing from the Census Bureau's automated download Web site.

Table 2.4 shows the trends in CPS and ECI incidence rates, as well as the trend in ECI health insurance costs, measured here relative to compensation in the form of a share. Note that the compensation share fell substantially over the early 1994 to 2000 period. The ECI for health insurance benefits did, in fact, become negative (or effectively zero) for some isolated quarters over this time period. Over the later 2000 to 2007 period, the health insurance share in compensation rose by more than enough to offset the early period decline.

Figure 2.7 juxtaposes March CPS and ECI incidence measures by position in the wage distribution. Here wage position is summarized by quintiles; I use coarser wage distributions because March CPS data has fewer observations and, perhaps, different wage measures than the CPS ORG data referenced earlier. As expected, the ECI positive cost incidence measure exceeds

Table 2.4

Health insurance plan trends

\begin{tabular}{cccc}
\hline & \multicolumn{2}{c}{ ECI Data } & \\
\cline { 2 - 3 } Year & $\begin{array}{c}\text { Fraction } \\
\text { positive } \\
\text { costs }\end{array}$ & $\begin{array}{c}\text { Share of } \\
\text { compensation }\end{array}$ & $\begin{array}{c}\text { March CPS } \\
\text { coverage fraction, } \\
\text { FTYR workers }\end{array}$ \\
\hline 1992 & .820 & .065 & .707 \\
1993 & .816 & .066 & .710 \\
1994 & .808 & .065 & .701 \\
1995 & .796 & .062 & .682 \\
1996 & .797 & .060 & .688 \\
1997 & .786 & .057 & .681 \\
1998 & .784 & .056 & .683 \\
1999 & .785 & .057 & .689 \\
2000 & .787 & .059 & .674 \\
2001 & .803 & .062 & .668 \\
2002 & .804 & .066 & .658 \\
2003 & .800 & .070 & .653 \\
2004 & .793 & .072 & .647 \\
2005 & .793 & .075 & .640 \\
2006 & .795 & .076 & \\
2007 & .788 & .077 & \\
\hline
\end{tabular}

Notes: March Current Population Survey (CPS) coverage rates refer to a sample of full-time, year-round (FTYR) workers (who usually work thirty-five or more hours per week, for fifty or more weeks in the year prior to the survey). The CPS sample is chosen to roughly correspond to the Employment Cost Index (ECI) scope and so excludes federal government and unincorporated self-employed workers, private household workers, and workers in agricultural industries. 


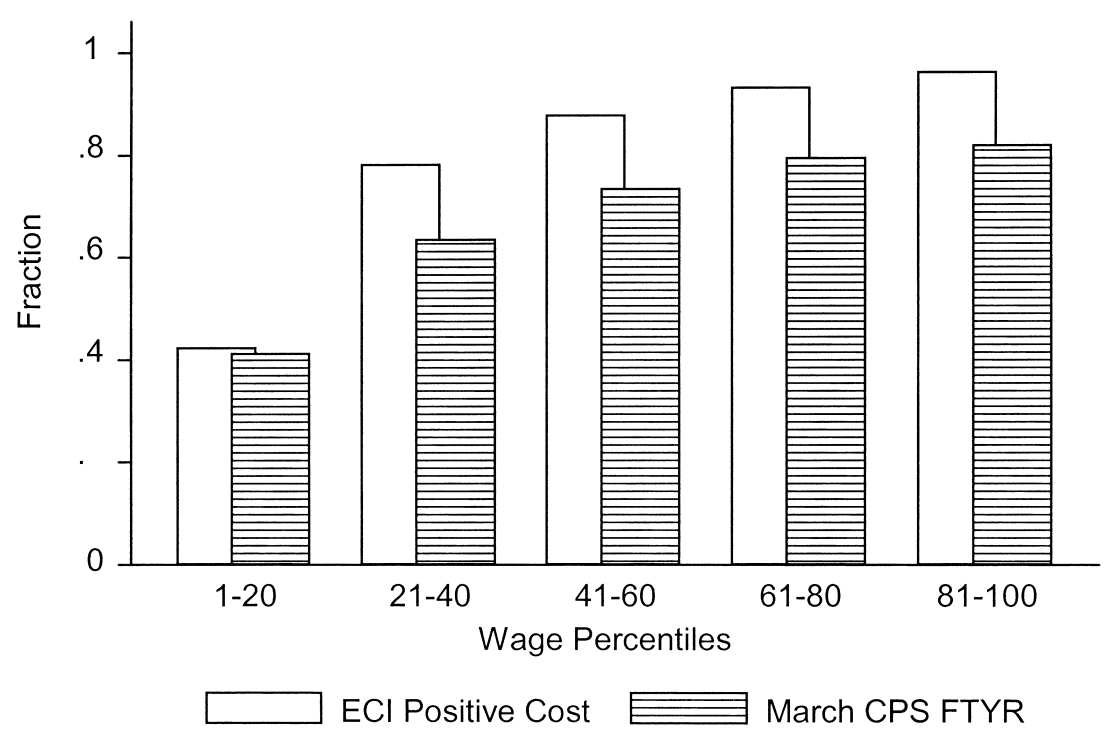

Fig. 2.7 Health insurance incidence by wage percentiles, 1992-2006 average

the CPS individual-based coverage rate. The difference between measures is fairly small in the bottom quintile but otherwise does not vary greatly with position in the wage distribution.

Figure 2.8 compares the CPS coverage rate over time at different points in the wage distribution. The coverage rate fell over time for each quintile group. The decrease was not particularly greater at lower than higher wage quintiles. Figure 2.9 shows the comparable figure using the ECI incidence measure. The ECI measure fell, but only modestly, over this period. One hypothesis is that the health insurance coverage rate declines found in the CPS data are more due to declining rates of take-up than to declining rates of employer offer. Of course, health insurance offers typically come conditional on worker contributions to costs, and employers may have changed the terms of offer over this period (Blostin and Pfuntner 1998). One implication is that the cost data in the ECI will reflect not only general health insurance premium inflation, but also any declining propensity for workers to enroll in employer-based health plans. However, the CPS data appears to imply that changing take-up rates were not a substantial cause for the differences by percentile in the health insurance share growth exhibited in figure 2.6 during the later 1997 to 2007 decade. The ECI coverage rates did fall, and disproportionately so, in lower wage jobs in the 1987 to 1992 period. Other CPS data (Farber and Levy (2000)) suggest falling coverage rates during that period as well, so it is likely that changing coverage or take-up patterns can explain some of the distributional patterns in the 1987 to 1997 period displayed in figure 2.6. 


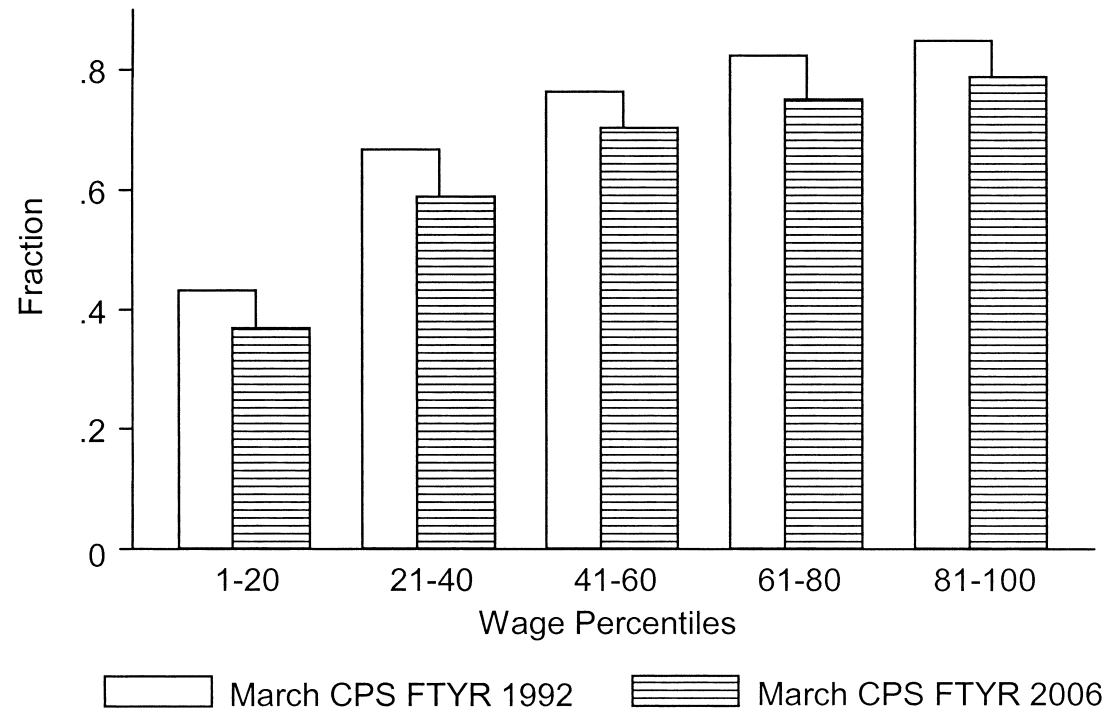

Fig. 2.8 Health insurance incidence by wage percentiles, 1992 and 2006

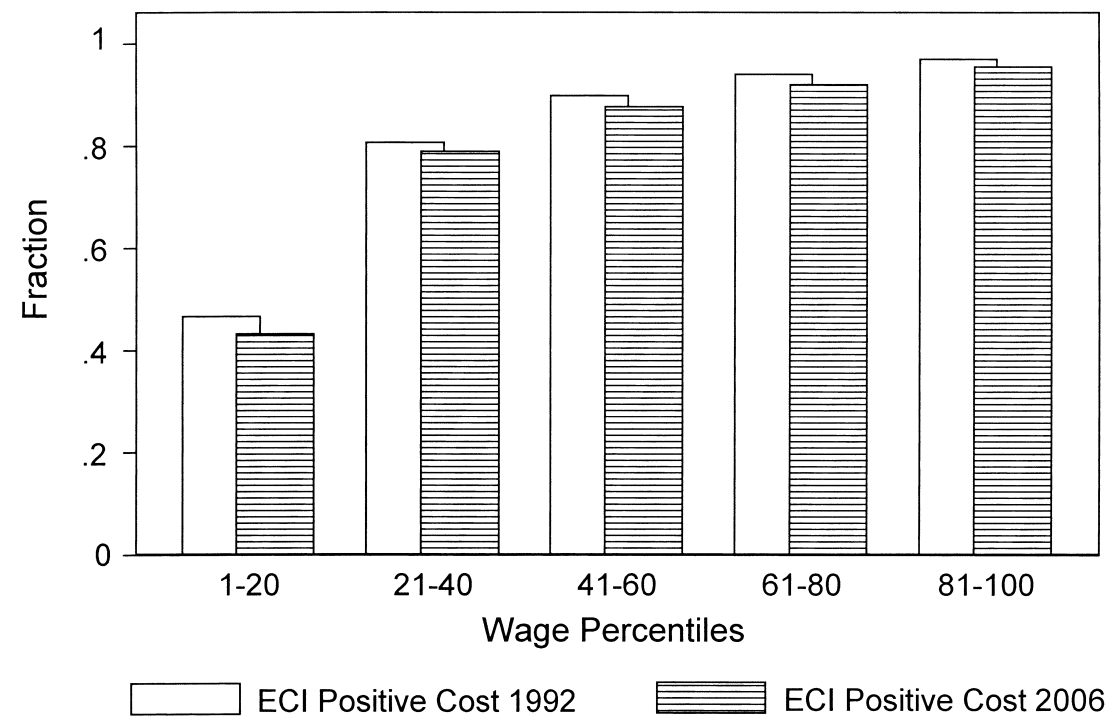

Fig. 2.9 Health insurance incidence by wage percentiles, 1992 and 2006 


\subsubsection{Retirement and Savings Plans}

Figure 2.10 gives benefit cost share series for the retirement and savings category. For the whole period change, the series are noisy, and no large change is apparent. It is safe to say that the percentile range chosen for analysis matters. Over the 1997 to 2007 subperiod, there is some evidence that retirement benefits have contributed to increased dispersion in compensation in above-median wage jobs.

In describing the trends in retirement and savings plan costs, it is useful to distinguish between defined benefit (DB) and defined contribution (DC) plan costs. The ECI began separately publishing statistics for these categories in 1996. The DB and DC plans tend to look different in terms of the distributional accounting. Figure 2.11 shows the fraction of the sample, as averaged across the years 1996 to 2007, with positive employer costs at given wage percentile for each of the two categories. The DC plan costs tend to be more prevalent than the DB plan costs, especially at and below the 80th percentile wage. Figure 2.12 gives benefit shares for DB and DC plans separately. The DB plan costs exceed the DC plan costs, on average, over this period. This is entirely an above-median phenomenon.

The whole period averages in figures 2.11 and 2.12 obscure some important trend changes. Table 2.5 shows these trends. Of course, DC plans have become increasingly prevalent, while no new DB plans (other than cash balance plan conversions) have been started for (literally) years. But table 2.5 also shows some important changes in the employer costs associated with the two types of plans. The DC plan cost shares increased slightly

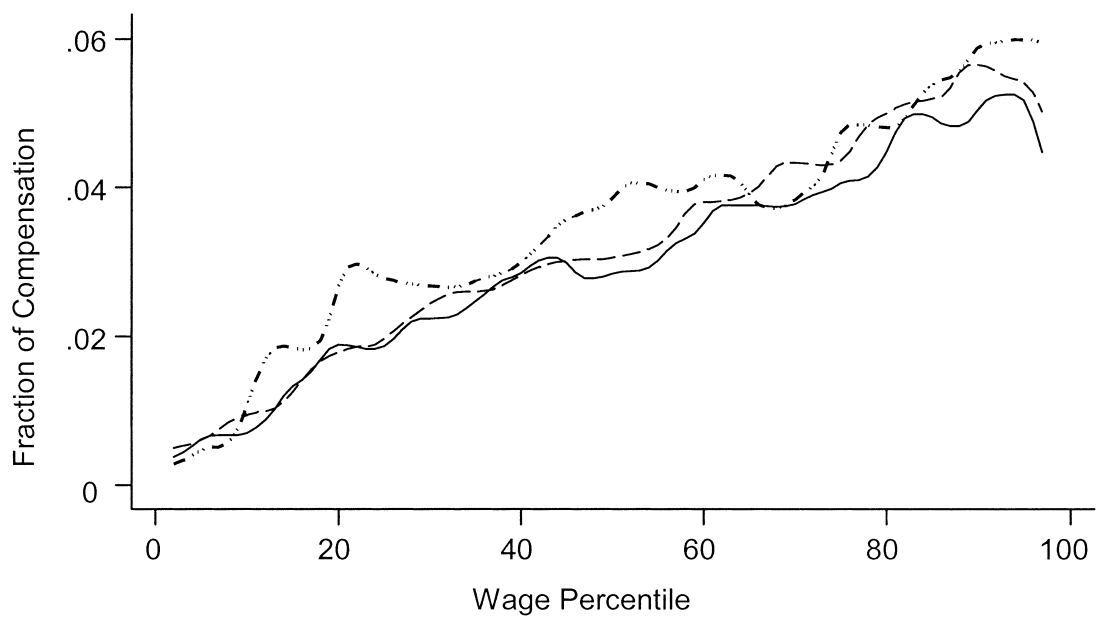

$-\cdots-\cdots-\cdots-1987$ 1997

Fig. 2.10 Retirement share by wage percentile 


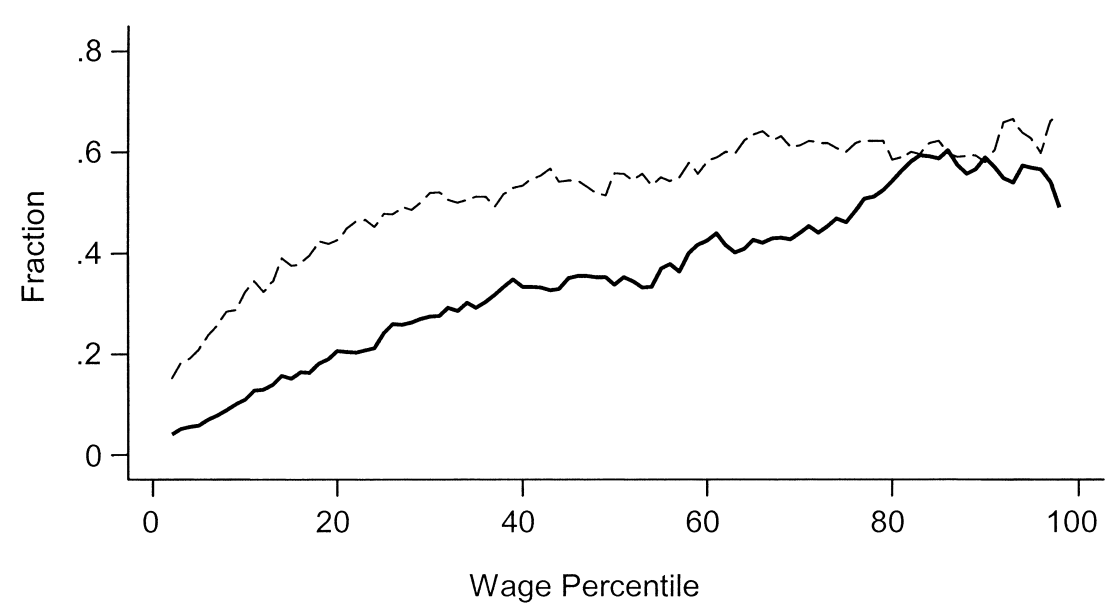

DB Plans $\quad------$ DC Plans

Fig. 2.11 Fraction with positive retirement plan costs, 1996-2007 average, by wage percentile

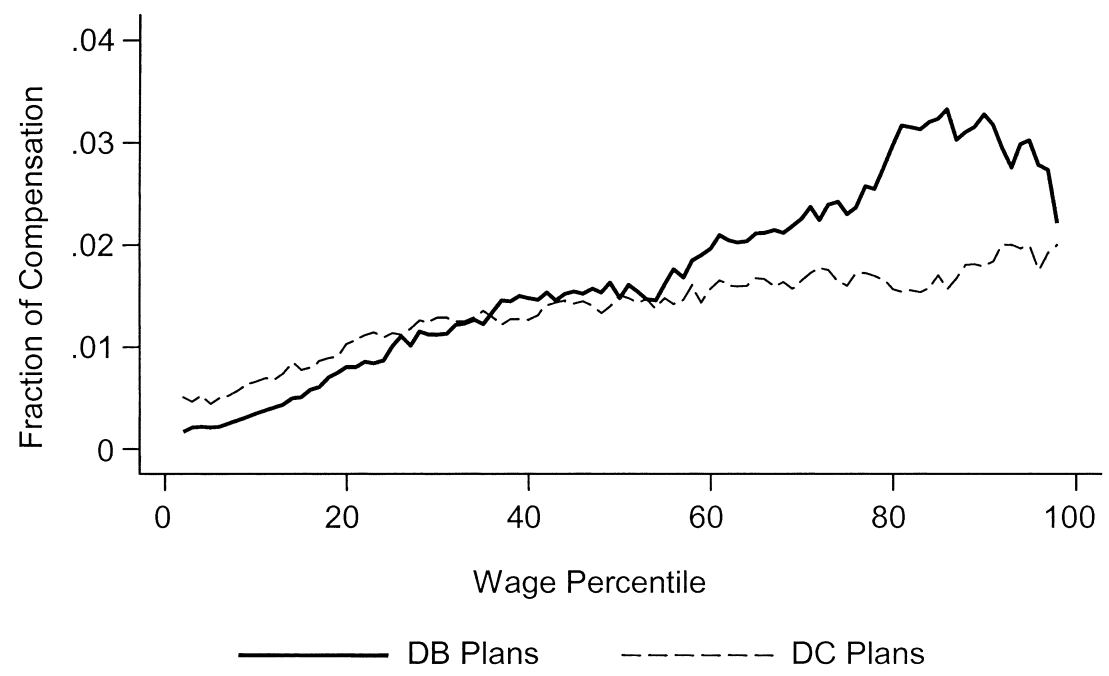

Fig. 2.12 Retirement plan benefit shares, 1996-2007 average, by wage percentile

over this period. However, the DB plan costs fell substantially from 1996 to 2002 , then rose tremendously over the following short period of time. From 2002 to 2007, the DB plan costs per hour rose about 50 percent. The rapid change after 2002 is widespread in the ECI data and is not due to sample turnover. This rapid increase is likely a response to falling pension 
Retirement and savings plan trends

\begin{tabular}{cccccc}
\hline & \multicolumn{2}{c}{ Defined benefit plans } & & \multicolumn{2}{c}{ Defined contribution plans } \\
\cline { 2 - 3 } \cline { 5 - 6 } Year & $\begin{array}{c}\text { Fraction } \\
\text { positive costs }\end{array}$ & $\begin{array}{c}\text { Share of } \\
\text { compensation }\end{array}$ & & $\begin{array}{c}\text { Fraction } \\
\text { positive costs }\end{array}$ & $\begin{array}{c}\text { Share of } \\
\text { compensation }\end{array}$ \\
\hline 1996 & .413 & .019 & & .436 & .011 \\
1997 & .384 & .018 & & .451 & .012 \\
1998 & .370 & .017 & & .465 & .012 \\
1999 & .354 & .016 & & .490 & .013 \\
2000 & .337 & .014 & & .508 & .014 \\
2001 & .335 & .014 & & .539 & .015 \\
2002 & .336 & .013 & & .541 & .014 \\
2003 & .338 & .014 & & .545 & .014 \\
2004 & .338 & .018 & & .544 & .014 \\
2005 & .338 & .019 & .547 & .014 \\
2006 & .326 & .019 & .559 & .014 \\
2007 & .312 & .018 & .561 & .014 \\
\hline
\end{tabular}

Note: The Bureau of Labor Statistics began publishing separate statistics for defined benefit and defined contribution plans with 1996 data.

funding levels brought on by declines in the market value of stocks. Pension fund assets include company stock, and falling stock values eventually require further dedication of assets to maintain fund solvency. The observed time lag accords with accounting rules allowing averaging or smoothing responses to plan underfunding over multiple years. ${ }^{7}$

Because DB plans have a larger effect on above-median wage jobs, this surge in DB plan contributions had a noticeable impact on compensation growth above the median and on compensation dispersion measures. It is likely that DB compensation cost growth above the median understated true values of added actuarial pension obligations early in this period (when stock values were rising) and overstated true values in the more recent past. The DB plan cost growth, at least as measured in the ECI data, slowed in 2007 to 2008, but a recent large stock market downturn may reverse this trend. Whether DB plan costs are a near-term driver for compensation dispersion increases will likely depend on what happens to DB pension funding levels going forward.

\subsubsection{Variable Pay: Nonproduction Bonuses and Incentive Pay}

Lemieux, MacLeod, and Parent (2007) suggest that performance-pay jobs were important vehicles for changing wage inequality during the 1980s, especially at the top end of the male wage distribution. The ECI data do have

7. Pension Benefit Guarantee Corporation (PBGC) premium revenues rose substantially after 2002, reflecting deteriorating plan funding (PBGC 2006, available at www.pbgc .gov/docs/2006databook.pdf). 
some information relevant to the general question of whether variable pay is an important conduit for wage growth. ${ }^{8}$

The ECI data distinguish between variable pay directly tied to individual worker product and other bonuses. Variable pay directly tied to worker product includes piece rates and sales commissions. Those payments are reported as part of worker earnings and are not broken out separately. However, in more recent ECI data, jobs subject to such production bonuses are identified separately. Those jobs are referred to here as "incentivepay" jobs.

Bonuses not tied directly to individual worker product are reported separately from earnings. Examples of such bonuses might include end-of-year payments tied to revenues generated by a broader employee group or business line. Those payments are referred to here and in BLS tabulations using these microdata as "nonproduction bonuses." These payments are the main component of the "other voluntary" or "other nonlegally required" benefits categories shown in table 2.2. ${ }^{9}$

Over the 1994 to 2007 period, on average, about 5.8 percent of the jobs in the ECI are incentive-pay jobs. As is well-known, these jobs are often salesrelated or managerial jobs, but incentive-pay jobs also appear in service and blue-collar occupations as well. Figure 2.13 gives the 1994 to 2007 average incentive-pay incidence fraction by wage percentile. The figure shows that these jobs are observed broadly throughout the wage distribution. Jobs with above-median wages are somewhat more likely to have an incentive-pay component. However, jobs with wages in the very upper tail are much more likely to have an incentive-pay component. For instance, over the 1994 to 2007 period, 14.6 percent of jobs in the upper 3.5 percent of wages have an incentive pay component. ${ }^{10}$ Incentive-pay jobs in the very upper tail of the wage distribution are often in financial services industries.

Over the 1994 to 2007 period, the ECI samples show a slight decrease in the fraction of jobs with incentive-pay components. The 1994 figure is 6.2 percent versus a 5.2 percent figure for 2007. The profile with respect to the wage distribution does not appear to exhibit any pronounced trend. That is, incentive-pay jobs do not appear to have become increasingly concentrated in higher-wage jobs over this period.

About 38.4 percent of the ECI data over the 1987 to 2007 period have positive nonproduction bonuses. Figure 2.14 shows this fraction by wage percentile for the 1987 to 2007 pooled period. Note that the fraction with

8. I thank Anthony Barkume for helpful discussions on variable pay.

9. The ECI survey scope excludes workers who set their own pay, including owners and directors who might be paid substantially via nonproduction bonuses. The intent is to restrict the data to arms-length transactions. Tips are not part of any compensation in the ECI.

10. Incentive-pay jobs tend to pay more than observationally similar jobs without incentivepay mechanisms (Barkume 2004). The wage premium might reflect induced effort, risk premiums, unobserved positive selection on ability, or other factors. Other BLS establishment survey data also show, at least in recent data, that incentive-pay jobs tend to have greater within-job wage dispersion. As discussed earlier, ECI data do not capture that variability. 


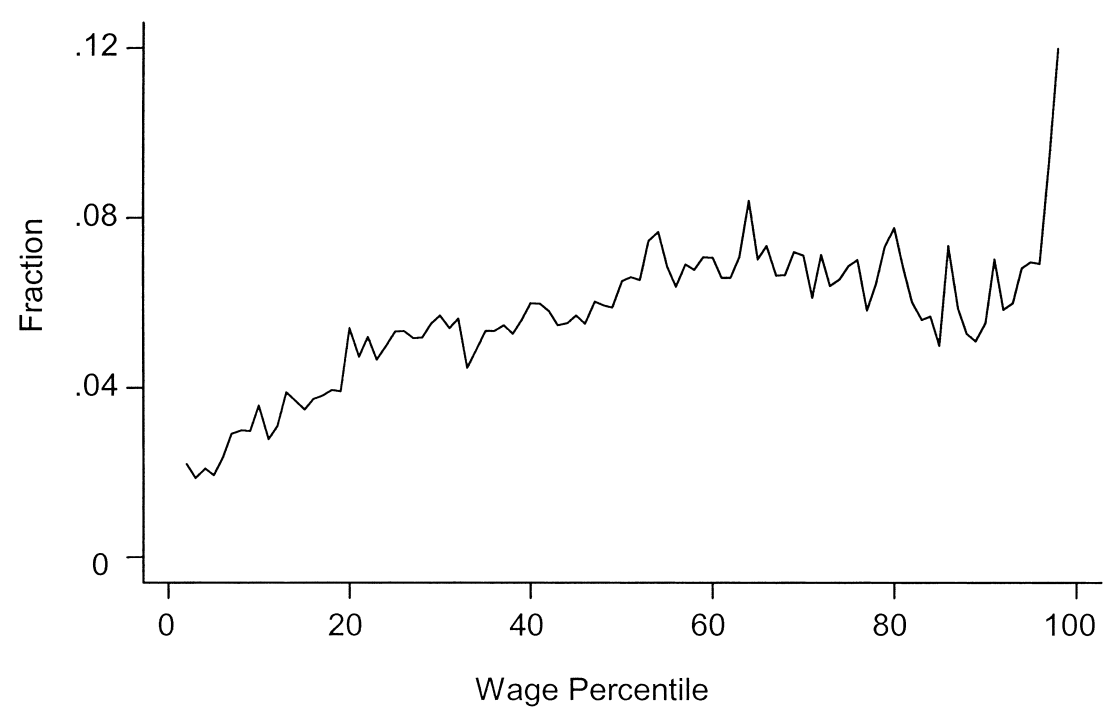

Fig. 2.13 Fraction with incentive pay, 1994-2007 average, by wage percentile

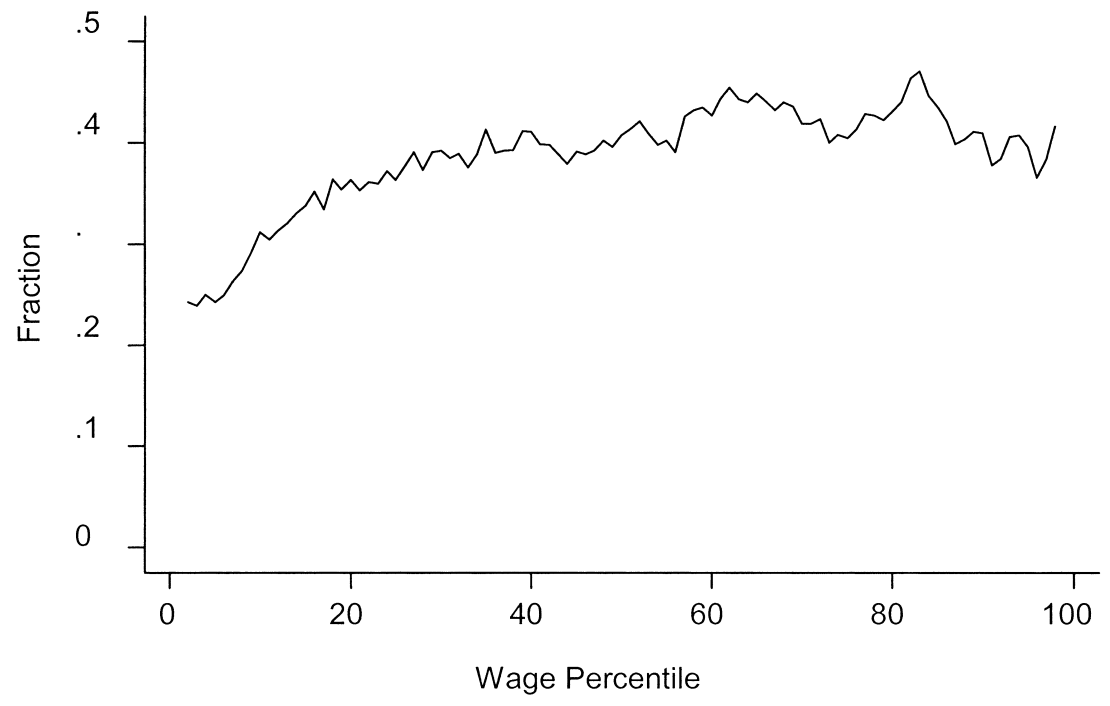

Fig. 2.14 Fraction with nonproduction bonus, 1987-2007 average, by wage percentile

positive nonproduction bonus payments is higher in above-than belowmedian wage jobs. However, there is not an apparent uptick in incidence at the highest wage levels.

Figure 2.15 shows the fraction of compensation attributable to nonproduction bonuses, conditional on receiving such a bonus, by wage percentile for the pooled 1987 to 2007 period. The figure shows the raw averages plotted 


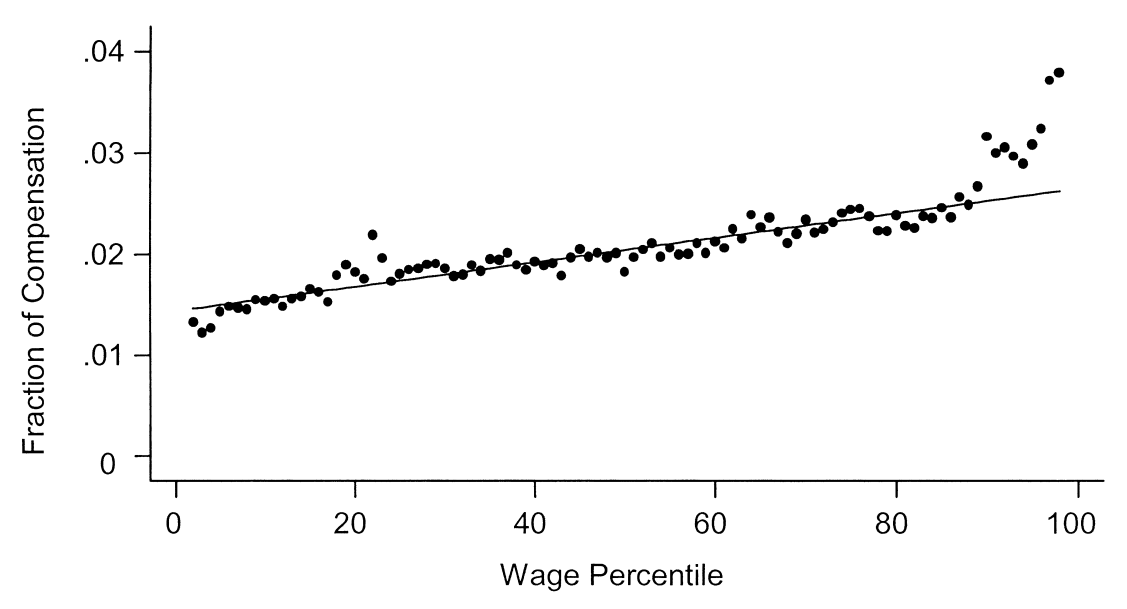

- Actual

Regression Line

Fig. 2.15 Bonus share conditional on receipt, 1987-2007 average, by wage percentile

alongside a regression prediction based on the lower 90 percentiles. Clearly the upper decile has nonproduction bonus payments exceeding what one might expect based on patterns in the lower 9 deciles. Taken together, figures 2.14 and 2.15 indicate that nonproduction bonuses tend to increase dispersion in the cross section; this is why the statistics in the "other voluntary" column of table 2.2 are consistently positive. Figures 2.14 and 2.15 further indicate that dispersion may be more sensitive to nonproduction bonus payments in jobs in the upper wage decile than elsewhere in the distribution, a result not apparent from table 2.2.

Figure 2.16 shows the fraction of compensation attributable to nonproduction bonuses by wage percentile, in 1987, 1997, and 2007. Although the scale of change is small relative to the wage growth shown in figure 2.5 , figure 2.16 shows that increased nonproduction bonuses in jobs in the upper half of the wage distribution did contribute to increased compensation dispersion over this period. This contribution is most evident in the upper decile of the wage distribution.

To sum up, very-high-wage jobs tend to have a higher incidence of sales commissions and piece rate pay. Because we do not know sales commissions and other variable-pay components separately from other earnings, we cannot tabulate them as a source of wage growth. It is possible that fluctuations in those forms of variable pay could disproportionately affect compensation dispersion at the very top of the ECI distribution. The ECI does separately identify nonproduction bonuses. Such bonuses are not direct commissions or piece rates but are better thought of as discretionary annual payments from a bonus pool. Bonuses have acted (in an accounting sense) 


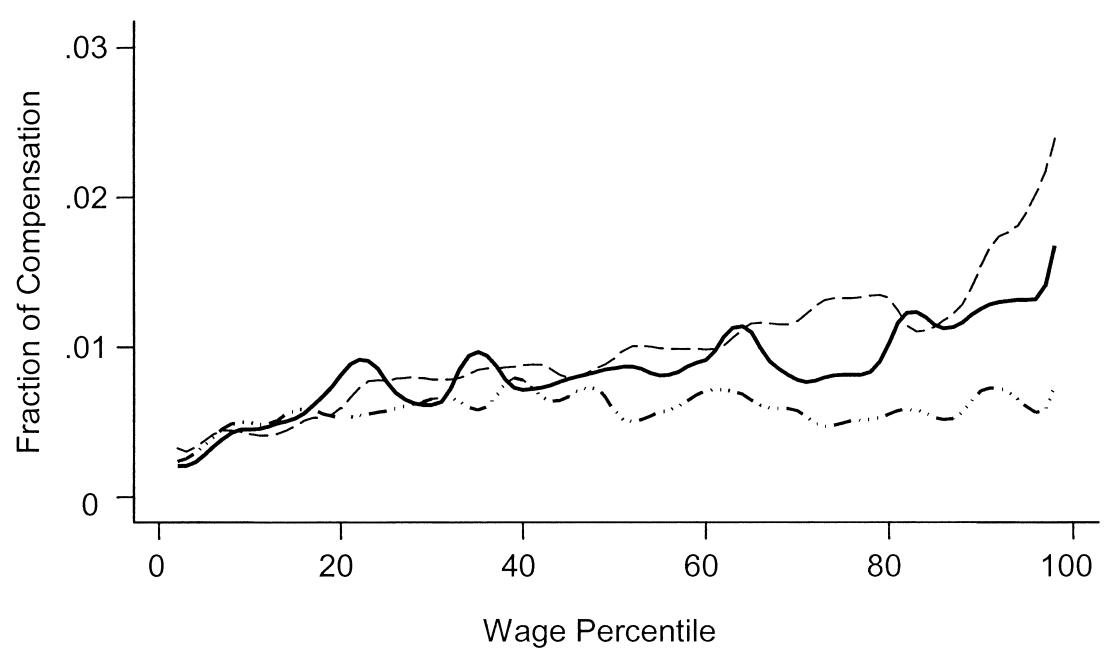

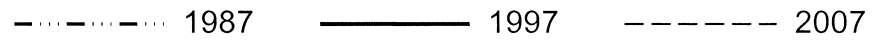

Fig. 2.16 Bonus share by wage percentile

to increase compensation dispersion above the median over the 1987 to 2007 period.

\subsubsection{Point Estimates}

Table 2.6 provides point estimates and standard errors for some of the trends described in the preceding. The first column gives the change in wage dispersion over the 1987 to 2007 period for the relevant percentile range. The next four columns give the contribution of benefit categories to compensation inequality, as operationalized by equation (1). The last column in the table gives changing dispersion in total compensation, where the distributional range continues to be defined based on points in the wage distribution. The point estimates for the benefit contribution columns are often small and not statistically different from zero. However, a case can be made that some health insurance cost changes contributed toward equalizing compensation differentials at or above the median wage, and contributed toward increased compensation differentials when comparing low-wage and median-wage jobs. Retirement and savings plan costs contributed only modestly to greater compensation dispersion in the upper half of the distribution. Leave costs growth tended to increase compensation dispersion over this period. For example, incorporating leave to obtain a better per-hour-worked wage measure would result in somewhat larger observed inequality growth in the ECI over this period.

As a general statement, it appears that including benefits costs in compensation measures would result in inequality growth at least as great as that 


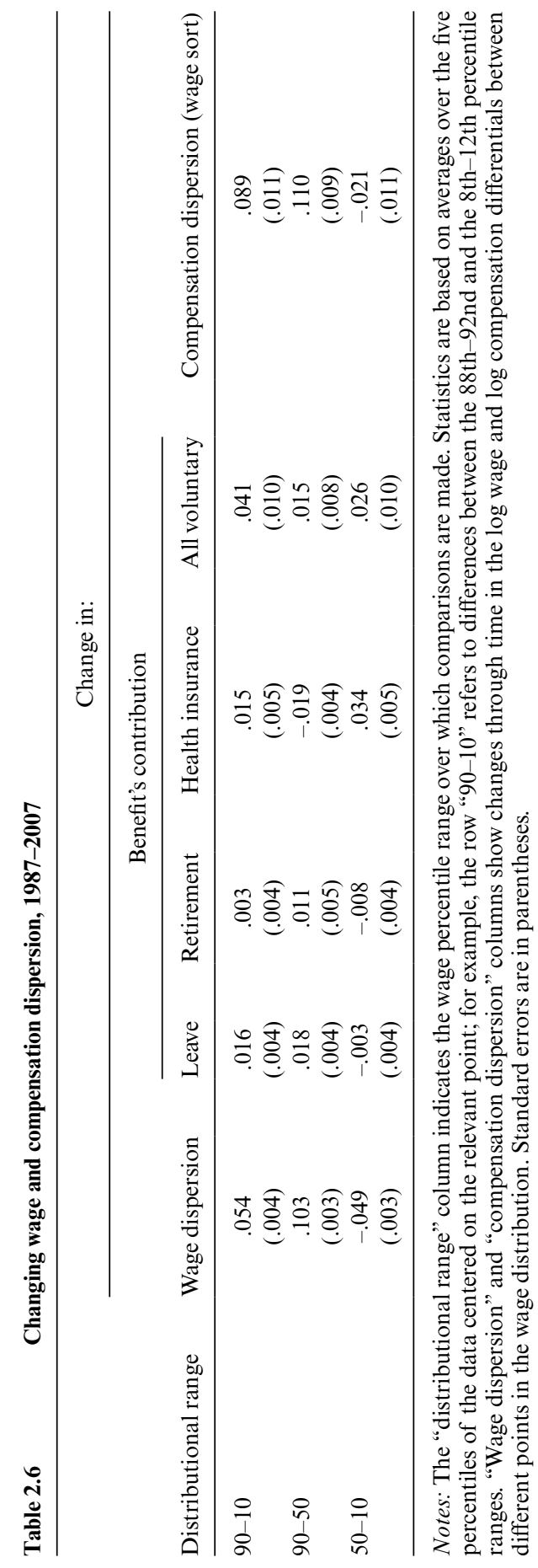


observed in wage rates alone. The reader will, of course, have noted that this result depends on time period and the particular inequality measures chosen. That, at least, is one advantage to looking at the nonparametric graphs presented earlier.

\subsection{Workplace Safety}

The discussion thus far has centered on costing out various forms of compensation that are not part of earnings. Of course, some job attributes are implicit and not so amenable to costing out in this fashion. Hamermesh (1999a,b) relates increased wage inequality and changing incidence of other such job attributes. This section discusses results for one attribute, workplace safety.

The BLS conducts the Survey of Occupational Injuries and Illnesses (SOII), an annual survey of employers used to estimate the number of nonfatal work-related injuries. As part of that effort, the BLS collects information on injured workers and the characteristics of the injuries for the subset of injuries that require days away from work (see Nestoriak and Ruser, chapter 11 in this volume). In addition, the BLS conducts an annual census of fatal work-related injuries (the Census of Fatal Occupational Injuries, or CFOI program). While these data do not include direct wage measures, they do include factors that correlate with wages, such as age and gender of the affected worker, the occupation held by the worker, and the industry of the employer.

In order to create graphs analogous to those in the preceding for health or pension benefits, I construct injury and fatality rates and plot them against wages. Wage positionals are calculated using CPS ORG wage data, and cell means of on-the-job injury and fatality risk are assigned to individuals and their associated wage positional. Individual risk is proxied with cell average risk.

To be more specific, I construct injury and fatality rates for cells given by year, gender, age group, coarse industry group (goods producing versus other), and occupation. The denominator for the rate statistics are cell totals for hours worked as constructed using CPS Basic Monthly survey data. These cell-specific injury rates are merged to CPS ORG individual level data. Individual wage rates form the basis for a wage positional, and the injury rate estimate for the individual's gender-age-industry-occupation cell is, in effect, an imputed work-related injury risk. Because occupation is an important correlate of wages and injury risk, I construct cells so that much of the variation in the data comes from the occupational dimension (there are five age groups, two genders, two industries, and approximately forty occupational categories). ${ }^{11}$ Because of changing occupational codes,

11. Hamermesh's (1999a) study on workplace safety used industry variation, for an earlier period. 
the time frame is limited to 1994 to 2002 data. The SOII data at the national level are available for private-sector workers.

Figure 2.17 shows the cross-sectional relationship between wage position and imputed work-related injury risk. Unlike earlier graphs, better work environments display as lower values in the graph (risk is a negative amenity). The relative injury risk for a cell during any year is the particular cell's injury rate for that year, divided by the year's injury rate aggregated over cells. Because the risk measure is relative, the measure averages to 1 within year. Figure 2.17 shows data for the entire pooled period. The obvious point is that higher wage workers are in cells with lower work-related injury risk. This appears to be especially true at the highest wage positions. Because much of the constructed variation is along occupational lines, this is a statement mainly about the occupations that high-wage workers occupy.

There were quite large declines in injury rates over this period. The rate of injuries and illnesses requiring days away from work fell from 2.8 per 100 full-time equivalent (FTE) workers in 1994 to 1.6 per 100 FTE in 2002. This raises a question of what sorts of occupations, industries, and workers disproportionately experienced those declines. Figure 2.18 tries to get at that question by graphing the begin- and end-of-period cross-sectional relationships analogous to the whole-period average shown in figure 2.17. Here the relative risk measure incorporates changes through time. That is, a cell's injury risk is now measured not relative to the year's average injury rate, but relative to the whole 1994 to 2002 average. To help eliminate noise,

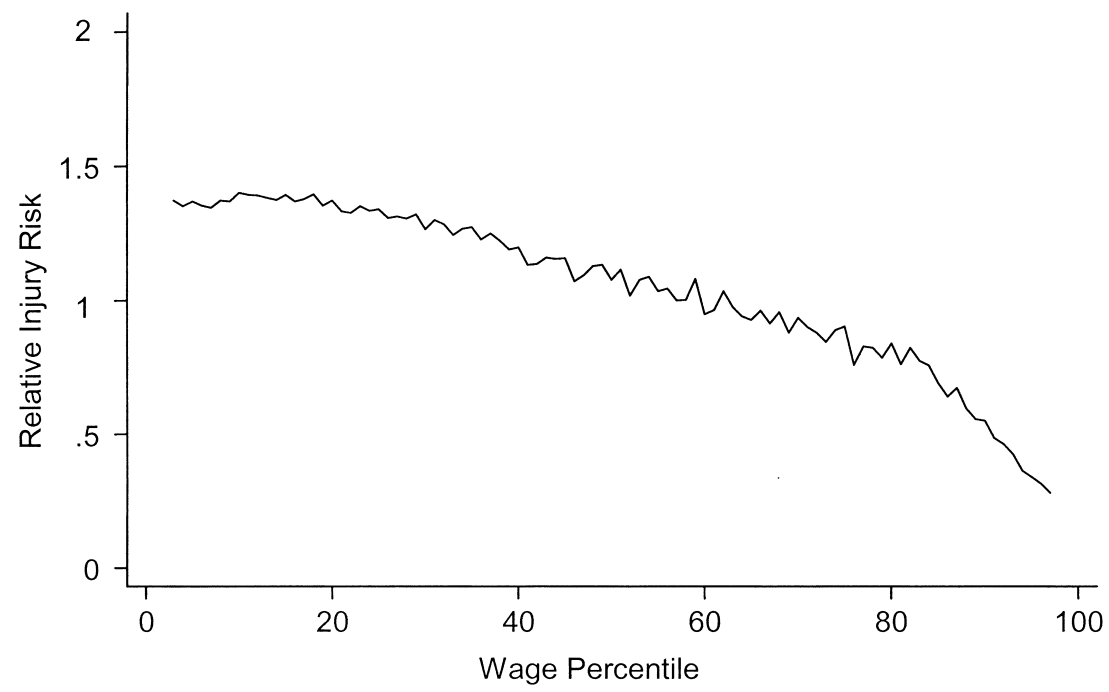

Fig. 2.17 Work-related injury risk, 1994-2002 average, by wage percentile 


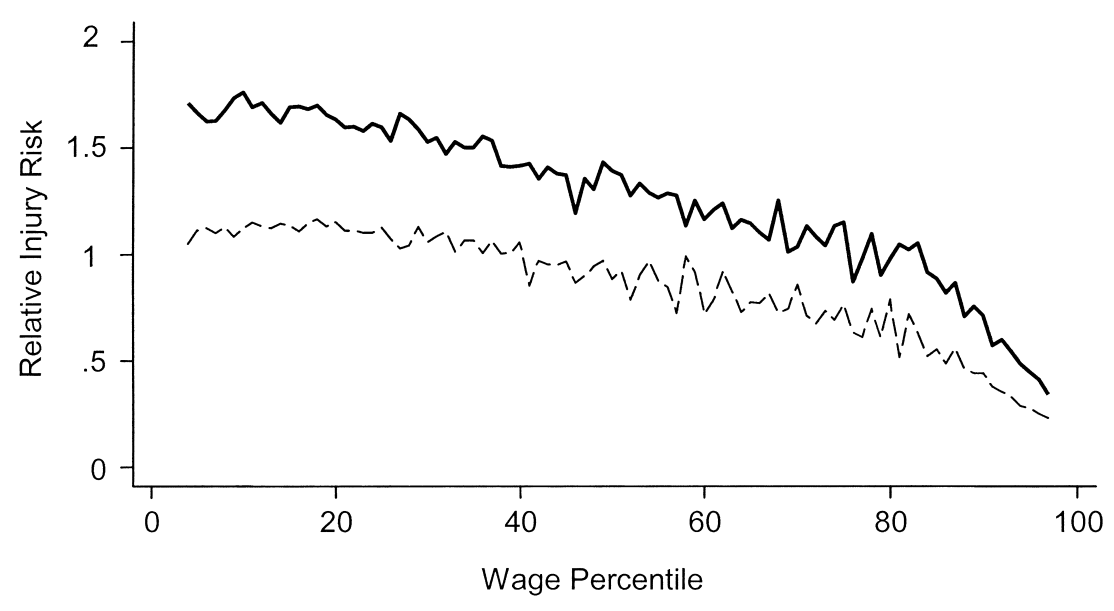

1994-96 ----- 2000-02

Fig. 2.18 Injury risk improvements by wage percentile

I average three years of data at the beginning and end of this time window, so the change is approximately a six-year change.

The risk measure shown here fell more for lower-wage workers. Because much of the variation here is along an occupational dimension, and because there is not much change over time in which cells are high-wage and which are low-wage, figure 2.18 implies the declining injury risk apparent in the total trend in injury rates is broad-based occupationally. In fact, injury rates are declining by similar proportions (but different percentage amounts) in almost all of the occupational categories used here. That is, the risk decline was proportionate to the initial probability of injury.

Figures 2.19 and 2.20 give analogous results for fatality rates. Fatalities are documented in the CFOI, an annual accounting of all work-related fatal injuries in the United States. To make results here comparable in scope to the earlier injury results, I restrict the analysis to private-sector employees. Fatality rates are constructed using employment and hours worked data from the CPS basic monthly files. Cells are the same as in the injury rate analysis, meaning that cells are defined by occupation, gender, age group, and coarse industry. As in the injury rate analysis, wage positionals are defined for CPS ORG data, and each individual is assigned a probability of fatality equal to the cell average fatality rate.

Figure 2.19 gives whole-period average relative risk. The plot actually slopes up in the lowest wage quintile and is roughly flat between, say, the 25 th and 75 th wage percentile. This is partly due to the very large gender differences in fatality propensity: women tend to have lower wages, and 


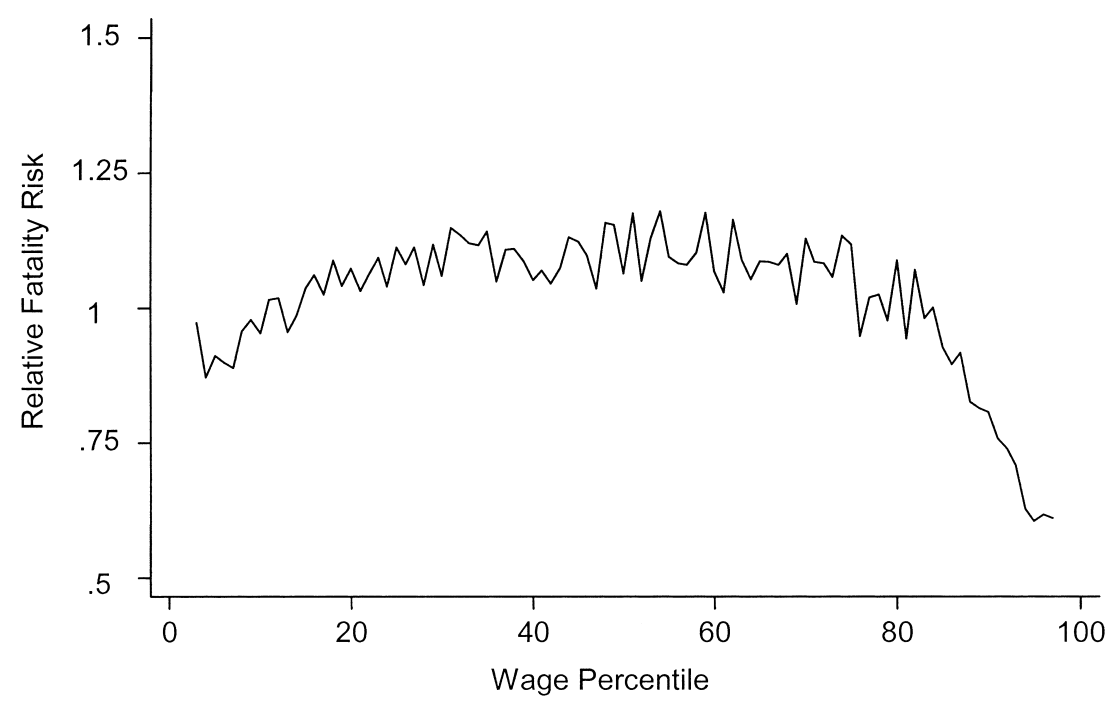

Fig. 2.19 Work-related fatality risk, 1994-2002 average, by wage percentile

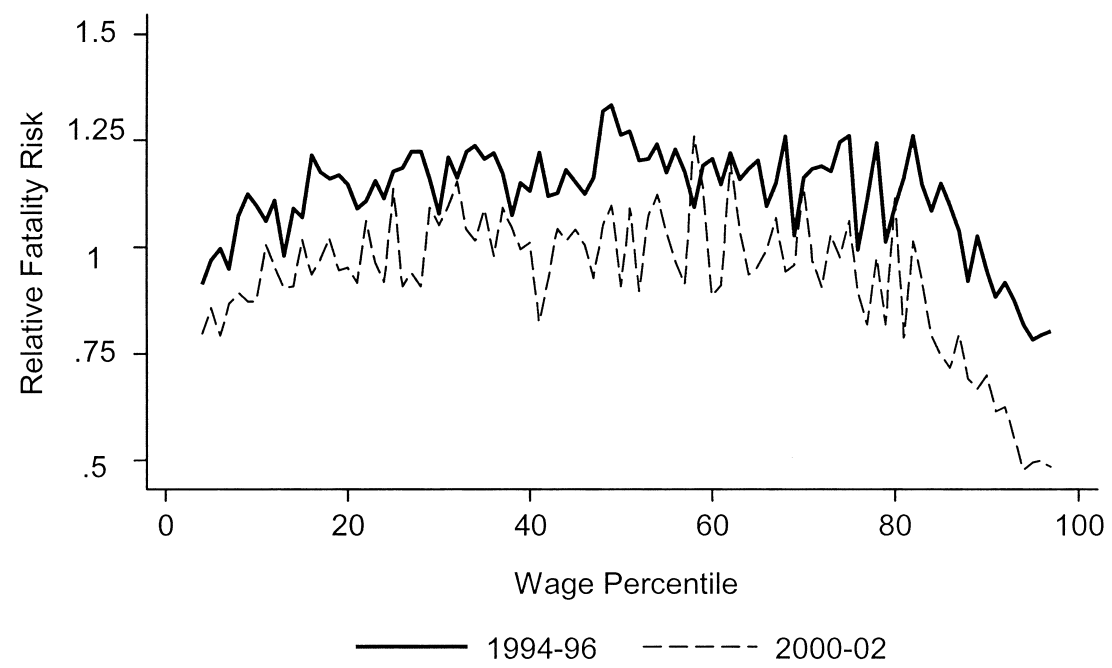

Fig. 2.20 Fatality risk improvements by wage percentile

women have a much lower propensity of suffering a work-related fatality. ${ }^{12}$ Beyond the 75 th percentile, the risk of fatality declines sharply as one moves

12. Were figure 2.19 restricted to male workers, the graph would show a downward sloping curve beyond approximately the 25 th percentile (where percentile still refers to place in the pooled distribution, not to the gender-specific distribution). The upward sloping and flat portions of figure 2.19 are due to gender composition shifts. However, the results shown in figure 2.20 are not at all sensitive to pooling men and women. 
up the wage distribution. The reader will note that the range of relative risk shown in figure 2.19 is smaller than that shown in figure 2.17 for fatalities. Note also that the plot for fatalities is noisier than that for injuries because fatalities are relatively rare events.

Figure 2.20 shows trend changes. As in figure 2.18, three-year averages are taken at the beginning and end of the period. For fatalities, there has been a fairly substantial reduction in risk over this period although the change is not of the same magnitude as the reduction in nonfatal injury risk. The reduction in fatality propensity was modestly larger in the upper quintile of the wage distribution. This is a somewhat different picture than the change in injury risk.

However, these are qualitative results, in the sense that risk is not pricedout, as the employer-provided benefits discussed earlier can be to some degree. Of course, this risk is notoriously difficult to price-out, and, in fact, these graphs serve as a reminder that compensating differentials for risk are often estimated to be negative. The most reasonable summary of these findings is that the safety improvements in figures 2.18 and 2.20 are widespread with respect to wage.

\subsection{Conclusion}

The intent of this chapter is to present facts on the level and distribution of fringe benefits, on the relationship between wages and fringe benefits, and on how these relationships have changed over the past two decades. It seems clear that health insurance premium increases acted to raise measured compensation more for workers in jobs in the broad middle of the wage distribution. There is some further evidence that other employer-provided benefits' costs rose most in those portions of the wage distribution experiencing the greatest wage growth. In total, inequality in compensation more broadly defined increased at least as much as wage inequality. It further appears that work-related safety risk improvement was broad-based and not concentrated in particular occupations over this period.

The changes documented here point to several interesting open questions. One set of questions relates to how wages and compensation adjust in response to the recessionary environment of 2008 to 2009. For example, there may be a recessionary impact on wages and bonuses in high-wage, incentive-pay jobs, which are frequently in sectors such as finance, which were particularly impacted by the recession. As another example, declining pension plan funding levels could eventually lead to greater employer pension contributions, especially for high-wage workers.

A second set of open questions relates to the labor market adjustments to more expensive health insurance. Because it has certain fixed cost attributes, rising premiums are especially likely to impact low-to moderate-wage 
workers with employer-provided health insurance coverage. To what extent will employers adjust by shifting employment to part-time or high-skill, long-hours jobs? Or pass on costs through required employee contributions or lowered wages?

A third open question is whether observed patterns in fringe benefit cost growth are partly attributable to income effects. If wages are rising faster for some workers than others, and if benefits or workplace amenities are income elastic, then wage inequality changes will cause predictable changes in benefits provisions. This is explicitly the view of Hammermesh (1999a,b) and Pierce (2001). Determining the extent of the income effects is challenging because conflating factors, including substitution effects, may differentially operate across the wage distribution. For example, it is not clear that technical innovations in workplace safety provision were neutral with respect to the wage. To the extent that fringe benefits are income elastic, benefits growth will tend to reinforce wage growth and broader-based compensation measures will give similar or slightly amplified patterns when calculating changing inequality.

\section{Appendix}

\section{ECI Microdata}

For background on the ECI, see also U.S. Department of Labor (1997).

\section{Panel Aspects and Weighting}

The ECI measures changing wages and compensation costs over a sample of fixed jobs. To do so, it follows panels of sampled establishments and jobs over multiple quarters. Sample replenishment takes the form of replacing a small fraction of establishments every quarter. The new subsample, except for subsequent attriters, remains in the ECI sample for approximately four and a half years. Sample weights are constructed at the time of initiation into the sample and reflect aggregate employment in the industry.

The panel aspect of the data raises some issues relevant to treating the data as annual cross sections. To correct for attrition, sample weights are adjusted quarter by quarter so that the cross section maintains a proper industry distribution. This reweighting does not correct for nonrandom attrition within industry or the fact that the distribution of sampled jobs is static within panel. This treatment is similar to what the BLS undertakes in producing its annual Employer Costs for Employee Compensation (ECEC) release. Also, cross sections are not independent at high frequencies. Finally, the data are hours-weighted. Published ECEC statistics are not hours-weighted. 


\section{Leave Costs and Scheduled Hours versus Hours Worked}

The ECI calculates leave costs as the hourly wage times the ratio of leave hours to hours worked (which is scheduled hours minus leave hours). A perfectly logical treatment would be to add leave costs so defined to the wage rate to obtain a better estimate of wages per hour worked. However, it is unlikely that CPS wage rates net-out leave time in this manner, and I, therefore, do not, in hopes of making wage measures across the two data sets more comparable.

\section{Within-Job Compensation Variation}

One way in which ECI-based inequality statistics differ from those based on household survey data is that the ECI microdata unit of observation is the job rather than the individual. The inequality statistics presented in the chapter are, therefore, interpretable as what one would observe using individual microdata, except that individuals' wages and benefit costs are proxied by their job averages. That is, one misses within-job wage and benefit cost dispersion. From a firm's perspective, this may not be very relevant - the within-job dispersion in, say, health insurance take-up rates may reflect ex post outcomes rather than ex ante expected costs - but it would be relevant from the perspective of the individual workers.

For wage rates, evidence from other establishment survey data suggests that relatively little of the total log wage variation is within-job (Groshen 1991). More recent evidence from another establishment survey, the National Compensation Survey, indicates that within-job log wage variance is on the order of 3 to 4 percent of total log wage variance (calculations by author). The sampling design and data collection for these surveys are similar, suggesting that wage dispersion measures as presented in the paper are quite like what would obtain were individual wage rates observed.

I have little evidence on within-job differences in benefit costs. Withinjob dispersion in legally required benefit costs should approximately equal the within-job wage dispersion because those costs tend to be direct functions of earnings. And obviously there is no within-job variance where costs are zero, which is a substantial portion of the data for some benefits. For observations with positive voluntary benefits costs, one can conceptually attribute within-job cost differences to differences in employer offers or in employees' take-up. One would expect within-job differences in employer benefit offers to be small because of nondiscrimination rules and the desire to be perceived as treating similar workers in a similar fashion. Note in this regard that ECI sampling treats full-time and part-time workers as occupying different jobs, even if they have the same job title (the same treatment holds for differences in union status and incentive-pay status). Therefore, any dispersion due to full-time or part-time differentials in health insur- 
ance (etc.) offers will be reflected in the ECI data as dispersion across jobs and so will be incorporated in the paper's inequality calculations. The data will, however, miss within-job differences in take-up or intensity of use for benefits, such as defined contribution plans and health insurance, which one suspects can be substantial.

\section{CPS Data}

\section{Outgoing Rotation Group (ORG) Data}

Outgoing panels from the CPS are asked supplemental questions on earnings, hours worked, and various aspects of their current job. These are fairly well-known data, and so I refer readers elsewhere for details (see, for example, Lemieux, chapter 1 in this volume). To construct data similar in scope to the ECI, I exclude agricultural industries, federal government and postal workers, the self-employed, and private household workers. The ECI survey scope explicitly excludes workers who set their own pay, so I exclude the self-employed, whether they are incorporated or unincorporated. Federal workers are identified separately from state and local government workers beginning in 1989 .

Hourly earnings are hourly wage rates for those reporting earnings on an hourly basis and are usual weekly earnings divided by usual hours worked per week for those reporting earnings with other than hourly periodicity. Topcoded earnings are multiplied by 1.5 prior to calculating hourly wages, which is a typical treatment in the literature. Very-low-wage rate observations $(<\$ 1$ nominal) are discarded. For the remaining distribution, wages are bottom-coded at one-half the minimum wage, topcoded at $\$ 200$ per hour, and deflated using the CPI-U. This is a similar treatment to the ECI microdata, except for the topcoding. In ECI data, very-high-wage rates arise from valid but large earnings responses; in CPS data, very-high wages often arise from suspiciously low reported hours. This topcoding treatment does not qualitatively alter the chapter's findings. Statistics are hoursweighted.

\section{March CPS Data}

Sections of this paper describing health insurance coverage use data from the March CPS supplements. March CPS data are retrospective, referring to individuals' prior year employment. The wage measure for the March sample is derived as annual wage and salary earnings, divided by the product of weeks worked and usual hours worked per week in the prior year. To construct data similar in scope to the ECI, I exclude agricultural industries, federal government and postal workers, the self-employed, and private household workers. I also restrict the CPS sample to full-time, year-round workers. At the time of this writing, March CPS data are available for years 
1992 to 2007 via the Ferret download system at http://dataferrett.census .gov/index.html.

\section{Injury and Fatality Data}

For background on these data, see also U.S. Department of Labor (1997) and Nestoriak and Ruser (chapter 11 in this volume).

The SOII is a large annual establishment survey that collects information on number and rate of nonfatal work-related injuries and illnesses. For the subset of injuries that result in days away from work, the SOII collects information about the affected workers and their cases. These data include age and gender, the occupation held by the worker, and the industry of the employer; they do not include earnings or hours worked by individuals. For national data the SOII scope is private employers, excluding small farms.

The CFOI is an annual census of all work-related fatalities in the United States. It is based on compiled information from multiple sources, including death certificates, Occupational Safety and Health Administration (OSHA) reports, police records, and media reports. The CFOI and SOII data have similar data fields. The scope of the fatality census is much broader than the SOII survey as it includes for example government employees and the self-employed. The BLS time series tabulations of fatalities typically exclude workers who died in the attacks of September 11, and I follow that convention here. In this chapter, I also restrict the fatality data to roughly correspond to the scope of the SOII data, primarily by excluding self-employed and government workers.

\section{References}

Autor, David H., Lawrence F. Katz, and Melissa S. Kearney. 2008. Trends in U.S. wage inequality: Revising the revisionists. Review of Economics and Statistics 90 (2): 300-323.

Baicker, Katharine, and Amitabh Chandra. 2006. The labor market effects of rising health insurance premiums. Journal of Labor Economics 24 (3): 609-34.

Barkume, Anthony J. 2004. Using incentive pay and providing pay supplements in U.S. job markets. Industrial Relations 43 (3): 618-33.

Bloom, David E., and Richard B. Freeman. 1992. The fall in private pension coverage in the United States. American Economic Review 82 (2): 539-45.

Blostin, Allan P., and Jordan N. Pfuntner. 1998. Employee medical care contributions on the rise. Compensation and Working Conditions 3 (Spring):46-51.

Famulari, Melissa, and Marilyn E. Manser. 1989. Employer-provided benefits: Employer cost vs. employee value. Monthly Labor Review 112 (12): 24-32.

Farber, Henry S., and Helen Levy. 2000. Recent trends in employer-sponsored health insurance coverage: Are bad jobs getting worse? Journal of Health Economics 19 (January): 93-119. 
Groshen, Erica. 1991. Sources of intra-industry wage dispersion: How much do employers matter? Quarterly Journal of Economics 106 (3): 869-84.

Hamermesh, Daniel S. 1999a. Changing inequality in markets for workplace amenities. Quarterly Journal of Economics 114:1085-1123.

1999b. The timing of work time over time. Economic Journal 109:37-66.

Lemieux, Thomas, W. Bentley MacLeod, and Danial Parent. 2007. Performance pay and wage inequality. NBER Working Paper no. 13128. Cambridge, MA: National Bureau of Economic Research, May.

Levy, Helen. 2006. Health insurance and the wage gap. NBER Working Paper no. 11975. Cambridge, MA: National Bureau of Economic Research, January.

Pension Benefit Guarantee Corporation (PBGC). 2006. Pension insurance data book, 2006. Alexandria, VA: PBGC.

Pierce, Brooks. 2001. Compensation inequality. Quarterly Journal of Economics 116 (4): $1493-1525$.

U.S. Department of Labor. 1997. Handbook of labor statistics. Bureau of Labor Statistics Bulletin no. 2490. Washington, DC: U.S. Department of Labor.

Woodbury, Stephen A. 1988. Substitution between wage and nonwage benefits. American Economic Review 73 (1): 166-82.

\section{Comment Daniel S. Hamermesh}

In his massive and comprehensive effort, Brooks Pierce has demonstrated a large body of new facts about the development of the American labor market in the last quarter century. The ones that seem most important are the following:

1. Except for the very highest centiles, the Current Population Survey (CPS) (worker-based) evidence that most of the rise in wage inequality has occurred entirely in the upper half of the wage distribution is confirmed and strengthened by employer-based evidence from the Employment Cost Index (ECI).

2. The growth in compensation inequality has been even sharper than that of earnings inequality, providing very strong evidence for a high income elasticity of demand for nonwage compensation.

3. The well-documented huge decline in workplace injury rates that occurred through the mid-1990s continued steadily through the early 2000s and, most interestingly, was matched by nearly as sharp declines in workplace fatalities. These decreases are observed at all points of the wage distribution.

I have no difficulties at all with most of Pierce's calculations and, indeed, admire both their breadth and depth. I am somewhat bothered by the treat-

Daniel S. Hamermesh is the Sue Killam Professor in the Foundations of Economics at the University of Texas at Austin, professor of labor economics at Maastricht University in the Netherlands, a research fellow of the Institute for the Study of Labor (IZA), and a research associate of the National Bureau of Economic Research. 